\title{
The Role of Dendritic Cells During Infections Caused by Highly Prevalent Viruses
}

\author{
Jorge A. Soto ${ }^{1}$, Nicolas M. S. Gálvez ${ }^{1}$, Catalina A. Andrade ${ }^{1}$, Gaspar A. Pacheco ${ }^{1}$, \\ Karen Bohmwald ${ }^{1}$, Roslye V. Berrios ${ }^{1}$, Susan M. Bueno ${ }^{1}$ and Alexis M. Kalergis ${ }^{1,2 *}$ \\ ${ }^{1}$ Departamento de Genética Molecular y Microbiología, Facultad de Ciencias Biológicas, Instituto Milenio de Inmunología e \\ Inmunoterapia, Pontificia Universidad Católica de Chile, Santiago, Chile, ${ }^{2}$ Departamento de Endocrinología, Facultad de \\ Medicina, Instituto Milenio de Inmunología e Inmunoterapia, Pontificia Universidad Católica de Chile, Santiago, Chile
}

\section{OPEN ACCESS}

Edited by:

Allan Randrup Thomsen,

University of Copenhagen, Denmark

Reviewed by:

Marina Cella,

Washington University School of Medicine in St. Louis, United States Johan Van Weyenbergh, KU Leuven, Belgium

${ }^{*}$ Correspondence: Alexis M. Kalergis akalergis@bio.puc.cl

Specialty section: This article was submitted to Viral Immunology, a section of the journal

Frontiers in Immunology

Received: 02 March 2020 Accepted: 09 June 2020 Published: 16 July 2020

Citation:

Soto JA, Gálvez NMS, Andrade CA, Pacheco GA, Bohmwald K,

Berrios RV, Bueno SM and Kalergis AM (2020) The Role of Dendritic Cells During Infections Caused by Highly Prevalent Viruses.

Front. Immunol. 11:1513.

doi: 10.3389/fimmu.2020.01513
Dendritic cells (DCs) are a type of innate immune cells with major relevance in the establishment of an adaptive response, as they are responsible for the activation of lymphocytes. Since their discovery, several reports of their role during infectious diseases have been performed, highlighting their functions and their mechanisms of action. DCs can be categorized into different subsets, and each of these subsets expresses a wide arrange of receptors and molecules that aid them in the clearance of invading pathogens. Interferon (IFN) is a cytokine -a molecule of protein origin- strongly associated with antiviral immune responses. This cytokine is secreted by different cell types and is fundamental in the modulation of both innate and adaptive immune responses against viral infections. Particularly, DCs are one of the most important immune cells that produce IFN, with type I IFNs ( $\alpha$ and $\beta$ ) highlighting as the most important, as they are associated with viral clearance. Type I IFN secretion can be induced via different pathways, activated by various components of the virus, such as surface proteins or genetic material. These molecules can trigger the activation of the IFN pathway trough surface receptors, including IFNAR, TLR4, or some intracellular receptors, such as TLR7, TLR9, and TLR3. Here, we discuss various types of dendritic cells found in humans and mice; their contribution to the activation of the antiviral response triggered by the secretion of IFN, through different routes of the induction for this important antiviral cytokine; and as to how DCs are involved in human infections that are considered highly frequent nowadays.

Keywords: dendritic cells, IFN, antiviral response, viruses, immune response

\section{INTRODUCTION}

Dendritic cells (DCs) are known to be professional antigen-presenting cells (APC), as these cells are capable of presenting processed peptides from various antigens, initiating and modulating the adaptive immune response by activating both $\mathrm{T}$ and $\mathrm{B}$ lymphocytes $(1,2)$. Therefore, they are considered to be of great importance for the induction of an adequate adaptive immune responses $(1,3)$. DCs were first reported in 1973 by Steinman et al., where their morphological characteristics were defined, although it was not until 1998 that their function, as well as the proteins expressed on their surface, were characterized $(1,4)$. Since then, the knowledge acquired about DCs has increased over time. 
During an infection, several molecules might be recognized and used to initially activate the innate immune system. These can be classified as pathogen-associated molecular or damageassociated patterns (PAMPs and DAMPs, respectively) $(5,6)$. These molecules will be recognized by pattern recognition receptors (PRRs) -expressed in most innate cells-, among which Toll-like receptors (TLRs), RIG-I-like receptors (RLRs), and NOD-like receptors (NLRs) are included. The interaction between PAMPs and PRRs promotes the release of cytokines, chemokines, and other chemical mediators that induce the inflammation of the infected tissue (7-9). TLRs are type I transmembrane glycoproteins that can be classified as extracellular or intracellular (10). Both TLR types have an N-terminal domain named leucine-rich repeat (LRR), a transmembrane domain, and a C-terminal cytosolic region named Toll/IL-1R (TIR). The main function of TLRs is to recognize a distinct set of ligands, such as proteins, genetic material, and carbohydrates (9-11). While ten different receptors of this type have been described up to date to be expressed by human cells, thirteen haven been described in mice $(12,13)$.

Identification of either PAMPs or DAMPs by immature DCs leads to the activation and consequent maturation of these cells $(14,15)$. This phenomenon is associated with changes in the phenotype and function of DCs, including the upregulation of costimulatory and adhesion molecules $(16,17)$. These cells are then capable of capturing antigens derived from pathogens, process, and present them to naïve $\mathrm{T}$ lymphocytes as peptides bound to class II major histocompatibility molecules (MHC) located on the surface of DCs. This structure is known as peptideMHC complex and works as a cognate ligand for the $\mathrm{T}$ cell receptor (TCR), expressed by $\mathrm{T}$ lymphocytes (18-20). Antigen cross-presentation can allow the presentation of exogenous antigens on class I MHC molecules (21). Aside from this, the main function of MHC-I is to present antigens derived from the cytosol (22).

DCs are considered to be of great relevance in the clearance of viruses. Accordingly, significant amounts of cytokines, such as type I interferon (IFN), are required to achieve this clearance (2, $23,24)$. In this review, we will discuss the classically and currently defined subsets of DCs, the importance of IFN in the antiviral response, and as to how DCs behave in some viral infections. This article aims to give insights into -and a better understanding ofthe role played by DCs in the antiviral response toward important human viruses.

\section{Classically Defined Subsets of DCs and Their Phenotypes}

Since their initial discovery, DCs have been deeply studied, and their immunophenotyping has allowed the definition of several subsets of DCs in the murine model, as well as in humans. Considering the immunobiology of the murine model, we highlight 2 important subgroups of DCs: conventional (cDCs) and plasmacytoid (pDCs). Both are derived from a common DC precursor (CDP), which is of myeloid origin $(25,26)$. Two precursor cell types arise from the CDP: a preDC and a prepDC. Moreover, the common lymphoid progenitor (CLP) has also been proposed to give rise to pDCs by numerous studies (2729), suggesting that this particular cell type has a mixed ontogeny. Furthermore, murine cDCs are classified into two subsets: $\mathrm{CDC} 1$ and $\mathrm{cDC} 2$, which develop in the bone marrow (30). The $\mathrm{CDC} 1$ compartment comprises CD $8 \alpha^{+}$DCs and CD103 ${ }^{+}$DCs, while the $\mathrm{cDC} 2$ compartment comprises $\mathrm{CD} 11 \mathrm{~b}^{+}$DCs (31). Recent findings regarding DC ontogeny are described in section SingleCell RNA-seq Approach for the Characterization of Novel DCs Subtypes and Precise DC Ontogeny.

Human homologs of these subtypes have been discovered through various comparative phenotypic and functional analyses and, more recently, through genomic, transcriptomic, and proteomic analyses. Human $\mathrm{CD} 141^{+} \mathrm{DCs}$ are homologous to both $\mathrm{CD} 8 \alpha^{+}$murine DCs and $\mathrm{CD} 103^{+}$murine DCs, human $\mathrm{CD}_{1} \mathrm{c}^{+} \mathrm{DCs}$ are homologous to murine $\mathrm{CD} 11 \mathrm{~b}^{+} \mathrm{DCs}$, and both humans and mice possess pDCs with similar functional characteristics (32). Classically defined DC sub-typing, their location, and commonly expressed surface markers can be found in Table 1. Functional and phenotypical characteristics of these cell types will be discussed in the following sections, and novel findings regarding DC subtypes will also be discussed.

\section{Murine DCs}

Among the murine $\mathrm{CDC} 1$ subset, $\mathrm{CD} 8 \alpha^{+}$DCs are of particular importance. As their name suggests, this class of DCs is characterized by the expression of a CD8 $\alpha \alpha$ homodimer (distinct from the $\mathrm{CD}^{+} \mathrm{T}$ cell $\mathrm{CD} 8 \alpha \beta$ heterodimer) $(37,61)$, although no clear biological function has been attributed to it (62). $\mathrm{CD} 8 \alpha^{+}$DCs reside in both central and peripheral lymphoid organs, namely thymus, spleen, and lymph nodes (62-64). Some of the PRRs expressed by this subset are TLR3, TLR9, and TLR11/12 (65-68), and unlike other DC subtypes, CD $8 \alpha^{+}$ DCs do not express TLR7 (68). These cells are capable of secreting large amounts of IL-12p70 upon activation (69), hence driving powerful $\mathrm{T}_{\mathrm{H}} 1$ responses when presenting antigens, and are specialized in cross-presentation of antigens on MHC-I molecules (70). These DCs are incapable of secreting interferon IFN- $\gamma$, although other DC subtypes do (69). Nonetheless, they are an important source of IFN- $\lambda$ once they are activated via TLR3 (71). CD $8 \alpha^{+}$DCs are characterized by surface expression of CD205, langerin (CD207), C-type lectin receptor 9A (CLEC9A), and chemokine receptor XCR1 (33-36) Finally, murine $\mathrm{CD} 8 \alpha^{+}$DCs are also $\mathrm{MHC}-\mathrm{II}^{+}, \mathrm{CD} 4^{-}, \mathrm{Ly}^{-} \mathrm{C}^{-}, \mathrm{CD} 11 \mathrm{~b}^{\mathrm{lo}}$, CD11c ${ }^{\text {hi }}, \mathrm{CD} 24^{\text {hi }}$, and B220-.

Another $\mathrm{cDC} 1$ subset relevant for the understanding of viral pathogenesis is the $\mathrm{CD}_{103^{+}}{ }^{\mathrm{DC}} \mathrm{C}$ compartment, characterized by the expression of the $\alpha \mathrm{E}$ integrin CD103. These cells are present in many tissues, including the gut, lungs, spleen, skin, and various lymph nodes (38). CD103 ${ }^{+}$DCs have a developmental relation with CD $8 \alpha^{+}$DCs (72) and share characteristic surface markers like CD24, CD205, and langerin (39-42). However, CD103 ${ }^{+}$DCs are capable of inducing a more robust $\mathrm{T}_{\mathrm{H}} 17$ response through IL-1 $\beta$ and IL- 6 secretion (73), and lack the expression of TLR3, although they remain responsive to polyI:C, a TLR3 agonist (74). Immunophenotyping has revealed an extensive heterogeneity among $\mathrm{CD}_{103}{ }^{+}$DCs, although some common features among each compartment are the expression of different surface markers 
TABLE 1 | DCs subsets, their location, and their surface markers.

\begin{tabular}{|c|c|c|c|c|c|c|}
\hline \multicolumn{2}{|c|}{ DCs subset } & \multirow{2}{*}{$\begin{array}{l}\text { Location } \\
\text { Lymphoid organs }\end{array}$} & \multicolumn{3}{|c|}{ Surface markers } & $\begin{array}{r}\text { Reference } \\
(33-36)\end{array}$ \\
\hline cDCs & Mouse cDC1 $\left(\mathrm{CD} 8 \alpha^{+}\right)$ & & $\begin{array}{l}\mathrm{MHC}^{-I^{+}} \\
\mathrm{Ly}^{-} \mathrm{C}^{-} \\
{\mathrm{B} 220^{-}}^{-} \\
\mathrm{CD}^{-}\end{array}$ & $\begin{array}{l}\mathrm{CD} 8 \alpha^{+} \\
\text {CD11blo } \\
\text { CD11 } c^{\text {hi }} \\
\text { CD24hi }\end{array}$ & $\begin{array}{l}\left.\mathrm{CD}^{205^{+}} \text {(DEC-205 }^{+}\right) \\
\left.\mathrm{CD}^{207^{+}}{ }^{+} \text {Langerin }^{+}\right) \\
\mathrm{CLEC9A}^{+} \\
\text {XCR }^{+}\end{array}$ & (33-36) \\
\hline & Mouse cDC1 (CD103+) & $\begin{array}{l}\text { Lymphoid organs and } \\
\text { Non-lymphoid organs }\end{array}$ & $\begin{array}{l}\mathrm{MHC}^{-I^{+}} \\
\mathrm{Ly}^{-} \mathrm{C}^{-} \\
\mathrm{B}^{-} 20^{-} \\
\mathrm{CD}^{-} \\
\mathrm{CD}^{-} 6^{+}\end{array}$ & $\begin{array}{l}\mathrm{CD}^{+} 0^{+} \\
\mathrm{CD}_{11 \mathrm{~b}^{+}} \\
\mathrm{CD}_{11 \mathrm{c}^{+}} \\
\mathrm{CD}^{+} 4^{+}\end{array}$ & $\begin{array}{l}\mathrm{CD} 103^{+} \\
\left.\mathrm{CD}^{+} 05^{+} \text {(DEC-205 }^{+}\right) \\
\left.\mathrm{CD}^{2} 7^{+}{ }^{+} \text {(Langerin }^{+}\right) \\
\text {XCR1 }^{+}\end{array}$ & $(37-43)$ \\
\hline & Human cDC1 (CD141'hi) & $\begin{array}{l}\text { Lymphoid organs and } \\
\text { Non-lymphoid organs }\end{array}$ & $\begin{array}{l}\text { CD11 } 1 c^{10} \\
\text { CD45 }\end{array}$ & $\begin{array}{l}\text { CD141 } \\
\text { CLi }\left(B D C A-3^{h i}\right) \\
\text { CLEA }^{+}\end{array}$ & $\mathrm{XCR}^{+}{ }^{+}$ & $(44-46)$ \\
\hline & Mouse cDC2 (CD11b+) & $\begin{array}{l}\text { Lymphoid organs and } \\
\text { Non-lymphoid organs }\end{array}$ & $\begin{array}{l}{\mathrm{MHC}-\mathrm{II}^{+}}^{\mathrm{F} 4 / 80^{-}} \\
\mathrm{CD}^{+} \\
\mathrm{CD}^{+} 1 \mathrm{~b}^{+}\end{array}$ & $\begin{array}{l}\mathrm{CD}_{11 \mathrm{C}^{+}} \\
\mathrm{CD}^{+} 4^{+} \\
\mathrm{CD}^{+} 4^{+}\end{array}$ & 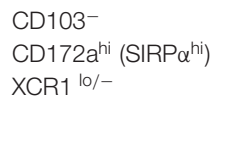 & $(47,48)$ \\
\hline & Human cDC2 $\left(\mathrm{CD} 1 \mathrm{c}^{+}\right)$ & Lymphoid organs & $\begin{array}{l}\mathrm{MHC}-\|^{+} \\
\mathrm{CD}^{\mathrm{lo} /+} \\
\mathrm{CD}^{\mathrm{l}} \mathrm{c}^{+}\left(\mathrm{BDCA}-1^{+}\right) \\
\mathrm{CD}_{11 \mathrm{c}^{+}}\end{array}$ & $\begin{array}{l}\mathrm{CD}^{-} 4^{-} \\
\mathrm{CD}^{-} 6^{-} \\
\mathrm{CD} 172 \mathrm{a}^{+}\left(\mathrm{SIRP} \alpha^{+}\right)\end{array}$ & $\begin{array}{l}\mathrm{XCR}^{-} \\
\mathrm{FCERI}^{+} \\
\left.\mathrm{CD}^{+} \mathrm{O}^{-}{ }^{-} \text {(Langerin }^{-}\right)\end{array}$ & $(47,49-53)$ \\
\hline \multirow[t]{2}{*}{ pDCs } & Mouse pDCs & $\begin{array}{l}\text { Blood, lymph nodes } \\
\text { and lymphoid tissues }\end{array}$ & $\begin{array}{l}{\mathrm{MHC}-\|^{\mathrm{lo}}} \\
\mathrm{CD}^{+} \\
\mathrm{CD}^{+} 1 \mathrm{~b}^{-} \\
\mathrm{B}^{-} 2 \mathrm{O}^{+}\end{array}$ & $\begin{array}{l}\mathrm{CD}_{11 c^{\mathrm{lo}}} \\
\mathrm{CD} 25^{\mathrm{lo}} \\
\mathrm{CD}^{+} 8^{+} \\
\mathrm{CD}^{-} 0^{-}\end{array}$ & $\begin{array}{l}\mathrm{CD} 43^{+} \\
\mathrm{CD}^{+} \mathrm{L}^{\text {mid }} \\
\text { Ly6C }^{\text {hi }}\end{array}$ & $(54-56)$ \\
\hline & Human pDCs & $\begin{array}{l}\text { Blood and bone } \\
\text { marrow }\end{array}$ & $\begin{array}{l}\mathrm{MHC}-\|^{\mathrm{o}} \\
\mathrm{B}^{\circ} 20^{+} \\
\mathrm{CD}^{-} \mathrm{a}^{-} \\
\mathrm{CD}^{+} \\
\mathrm{CD}^{+} 1 \mathrm{a}^{+} \\
\mathrm{CD}^{-} 1 \mathrm{C}^{-} \\
\mathrm{CD}^{-} 3^{-}\end{array}$ & $\begin{array}{l}\text { CD14- } \\
\text { CD16- } \\
\text { CD18 } \\
\text { CD33 }^{-} \\
\text {CD38 }^{\text {lo }} \\
\text { CD40 } \\
\text { CD44 }\end{array}$ & $\begin{array}{l}\mathrm{CD}^{+} 4^{+} \\
\mathrm{CD}^{+} \mathrm{L}^{+} \\
\mathrm{CD}^{+} 23^{+}\left(\mathrm{IL}-3 \mathrm{R} \alpha^{+}\right) \\
\mathrm{CD}^{+} 27^{-}\left(\mathrm{IL}-7 \mathrm{R} \alpha^{-}\right) \\
\left.\mathrm{CD}^{-}\right) 3^{+}\left(\mathrm{BDCA}-2^{+}\right) \\
\mathrm{CD}^{\circ} 4^{+}(\mathrm{BDCA}-4)\end{array}$ & $(57-60)$ \\
\hline
\end{tabular}

such as $\mathrm{Ly}_{6 \mathrm{C}}{ }^{-}, \mathrm{CD} 11 \mathrm{~b}^{+}, \mathrm{CD} 11 \mathrm{c}^{+}, \mathrm{CD} 80^{+}, \mathrm{CD}^{\circ} 6^{+}, \mathrm{B} 220^{-}$and, of course, $\mathrm{CD}_{103^{+}}$(38). Most of them are $\mathrm{CD} 8^{-}$, except for those that reside in the gut (namely, colon) (43) and spleen (37). Extensive murine subgroup immunophenotyping can be reviewed in del Rio et al. (38).

Importantly, $\mathrm{CD}_{103}{ }^{+}$DCs have enhanced antigen crosspresentation capacities, which is employed by the immune system for the resolution of some viral infections, as well as for the maintenance of self-tolerance and tumor immune control, since phagosome-derived peptides can be presented on MHC-I molecules to activate -or inhibit- cytotoxic $\mathrm{CD} 8^{+} \mathrm{T}$ cells $(75,76)$. Regarding viral infections, skin, and lung $\mathrm{CD}_{103}{ }^{+}$DCs subtypes have been shown to prime $\mathrm{CD} 8^{+} \mathrm{T}$ cells more efficiently than their $\mathrm{CD}_{103^{-}}$counterparts $(77,78)$, and those that are liverresident can prime $\mathrm{CD} 8^{+} \mathrm{T}$ cells in situ (79). On the other hand, mediastinal lymph node (80) and splenic marginal zone (81) $\mathrm{CD}_{103^{+}}$DCs contribute to the maintenance of self-tolerance through cross-presentation of self-antigens, especially to $\mathrm{CD} 4^{+} \mathrm{T}$ cells $(38,82)$. As a matter of fact, $\mathrm{CD} 103^{+}$DCs have been shown to secrete TGF- $\beta$ and induce the expression of the transcription factor Foxp3 on $\mathrm{T}$ cells, promoting the development of $\mathrm{T}_{\text {regs }}$ $(80,83,84)$.

Even though the $\mathrm{CDC} 2$ subset has been less studied than the $\mathrm{CDC} 1$ compartment, their contribution to the activation of an immune response should be deeply characterized. These cells reside in both lymphoid and non-lymphoid tissues, such as lungs and guts. Unfortunately, their characterization has been hampered by their innate heterogeneity (85-88), the lack of various specific $\mathrm{CDC} 2$ markers, and their similarity with macrophages and other members of the phagocytic mononuclear system $(89,90)$. However, recent transcriptomic studies have circumvented these difficulties, making it possible to characterize adequately these cells due to their development routes (91). Contrary to cDC1 cells, cDC2 cells do not efficiently crosspresent antigens. They can efficiently prime $\mathrm{T}_{\mathrm{FH}}$ cells $(92,93)$ and tend to polarize adaptive immune responses toward $\mathrm{T}_{\mathrm{H}} 17$ and $\mathrm{T}_{\mathrm{H}} 2$ profiles $(86,94-96)$. In addition, $\mathrm{cDC} 2 \mathrm{~s}$ have been proven to be relevant mediators of asthma-like responses (94), hypersensitivity responses (94), and infections of bacteria (97, 98), fungi (86), and parasites $(99,100)$. Moreover, they have been regarded as important modulators of mucosal immunity, given their abundance in the gut and respiratory tract (47). This subset expresses particularly high levels of TLR4, TLR5, and $\operatorname{TLR} 11(18,101,102)$, which partly differentiates them from other DC subsets. Their hallmark marker is CD172a (SIRP $\alpha$ ) and expresses virtually no XCR1, which are key characteristics for differentiating them from the $\mathrm{CDC} 1$ subset, (47). Phenotypically, these cells have been defined as $\mathrm{F} 4 / 80^{-}, \mathrm{MHC}-\mathrm{II}^{+}, \mathrm{CD} 4^{+}$, 
$\mathrm{CD}_{11} \mathrm{~b}^{+}, \mathrm{CD} 11 \mathrm{c}^{+}, \mathrm{CD} 24^{+}, \mathrm{CD}_{4}{ }^{+}, \mathrm{CD}_{103}{ }^{-}, \mathrm{CD} 172 \mathrm{a}{ }^{\mathrm{hi}}$, and $\mathrm{XCR} 1^{\mathrm{lo} /-}$ (47), although lamina propria-residing intestinal cDC2s are $\mathrm{CD} 103^{+}(48)$.

The last type of DCs we review are pDCs, which were first described in 2001 for mice (103) and in 1999 in human blood $(57,104)$. These cells are characterized both in mice and humans for their plasmacytoid appearance, their capacity to secrete large quantities of type I IFN $(57,103)$, and are mainly found circulating in the blood and secondary lymphoid organs (105-107), although they can migrate to inflamed skin (108), gut (109, 110), and epithelia (111). As mentioned above, pDCs arise not only from a myeloid precursor -the CDPbut also from a lymphoid precursor -the CLP-, giving this class of DCs a mixed ontogeny. Moreover, some murine pDCs may undergo conversion toward a cDCs phenotype $(112,113)$, which blurs the limit between myeloid and lymphoid DCs lineages even more. pDCs exhibit poor antigen presentation capabilities, are characterized by lower-than-average MHC-II levels in comparison to $\mathrm{CDCs}(54,55)$, and have been found to aid in plasma cell differentiation through type I IFN and IL6 secretion (114). Most notably, these cells represent a major source of IFN- $\alpha$ upon viral infections and express abundant TLR7 and TLR9 in their endosomal membranes (27). Regarding their pattern of expression of surface markers, the classical definition of pDCs involves medium-to-low levels of CD11c expression and high levels of B220, although such a definition may lead to confusion since it is too vague. Additionally, murine $\mathrm{pDCs}$ are $\mathrm{CD} 4^{+}, \mathrm{CD}_{11 b^{-}}, \mathrm{CD} 25^{\mathrm{lo}}, \mathrm{CD} 38^{+}, \mathrm{CD} 40^{-}, \mathrm{CD} 43^{+}, \mathrm{CD} 62 \mathrm{~L}^{\mathrm{mid}}$, Ly6 $\mathrm{C}^{\text {hi }}$, and, as previously stated, express lower MHC-II levels than $\mathrm{cDCs}$ (56).

\section{Human DCs}

In humans, CD141 hi DCs (BDCA-3 ${ }^{+}$DCs) represent the functional homolog of murine $\mathrm{CDC1}$ cells $\left(\mathrm{CD} 8 \alpha^{+}\right.$and $\mathrm{CD} 103^{+}$ DCs), mainly due to their similar localization-both are found in lymphoid and non-lymphoid tissues, such as thymus and lymph nodes, show enhanced antigen cross-presentation to $\mathrm{CD} 8^{+} \mathrm{T}$ cells, $\mathrm{T}_{\mathrm{H}} 1$ response polarization, and extensive secretion of TNF- $\alpha$ and IFN- $\alpha / \beta / \lambda$ under TLR3 activation $(44-46,71,115)$. Unexpectedly, a controversial study reported that CD141 ${ }^{\text {hi }}$ DCs secrete neither IL-23p19 nor IL-12p70 in response to TLR3 activation by polyI:C or a cocktail of pro-inflammatory cytokines (45). Nonetheless, other reports suggest that CD141 ${ }^{\text {hi }}$ DCs do indeed secrete IL-12p70 in response to TLR3 stimulation with polyI:C and other TLR3 agonists, further supporting the notion that these cells induce $T_{H} 1$ polarization $(44,115)$. CD141 ${ }^{\text {hi }} \mathrm{DCs}$ have been described as CD $11 c^{\text {lo }}, \mathrm{CD} 45^{+}, \mathrm{CD} 141^{\text {hi }}$ (BDCA- $3^{\text {hi }}$ ), and vastly express XCR1, CLEC9A, and TLR3 (44-46), consistent with their cross-presentation capabilities and activation by soluble nucleic acids.

On the other hand, $\mathrm{CD} 1 \mathrm{c}^{+} \mathrm{DCs}\left(\mathrm{BDCA}-1^{+} \mathrm{DCs}\right)$ are the human homolog of $\mathrm{CD}_{11 b^{+}}$murine DCs (cDC2s). These cells are present in blood, lungs, gut, skin, and lymphoid organs, such as the spleen, tonsils, and lymph nodes (88). In agreement with what has been observed in mice, human cDC2s express a wide variety of TLRs, such as TLR1, TLR2, TLR4, TLR5, TLR6, and TLR8 (116-118). Contrary to murine cDC2s, human
$\mathrm{CD}_{1}{ }^{+} \mathrm{DCs}$ are more versatile when priming $\mathrm{CD}^{+} \mathrm{T}$ cells and can also polarize them toward a $\mathrm{T}_{\mathrm{H}} 1$ profile $(117,119)$, which is consistent with their ability to secrete high amounts of IL-12 (117, 120), and have been shown to efficiently drive $\mathrm{T}_{\mathrm{FH}}$ responses (121). Moreover, they are also capable of crosspresentation of antigens to CD8 ${ }^{+} \mathrm{T}$ cells quite efficiently (120, 122). Thus, given their PRR repertoire and their cytokine secretion profile, $\mathrm{CD}_{\mathrm{c}}{ }^{+} \mathrm{DCs}$ are excellent APCs in the context of either bacterial, viral, or fungal infections. Lastly, regarding their surface marker expression profile, these cells are characterized as $\mathrm{MHC}-\mathrm{II}^{+}, \mathrm{CD} 1 \mathrm{a}^{\mathrm{lo} /+}, \mathrm{CD} 1 \mathrm{c}^{+}\left(\mathrm{BDCA}^{-1}{ }^{+}\right), \mathrm{CD} 11 \mathrm{c}^{+}, \mathrm{CD} 14^{-}$,

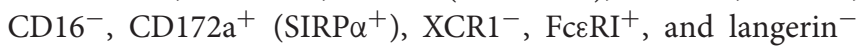
(47, 49-52), although CD1a, CD1c and langerin expression is variable and/or inducible $(50,53)$.

Finally, human pDCs (BDCA-2 ${ }^{+}$DCs) share many of their characteristics with murine pDCs: they are found mainly in blood, secrete high amount of IFN- $\alpha$ upon activation $(123,124)$, and share some but not all immunophenotypic characteristics since human $\mathrm{pDCs}$ are $\mathrm{CD} 4^{+}$and $\mathrm{B} 220^{+}$, but pDCs additionally have $\mathrm{CD}_{11 c^{-}}, \mathrm{CD}_{14}^{-}$and $\mathrm{CD}^{-} 6^{-}$as surface markers (58). It is important to note that pDCs' repertoire of PRRs is very specialized and consists almost exclusively of TLR7 and TLR9 $(58,123,125)$. Because of their enhanced type I IFN secretion and nucleic acid-oriented sensing of pathogens through endosomal TLRs, pDCs exhibit vast antiviral activities and are only mildly permissive to viral infections compared to $\operatorname{cDCs}(126,127)$. Moreover, they express lower-than-average levels of MHC-II and are $\mathrm{CD} 1 \mathrm{a}^{-}, \mathrm{CD}_{11 \mathrm{a}^{+}}, \mathrm{CD}_{13}{ }^{-}, \mathrm{CD} 18^{+}, \mathrm{CD} 33^{-}, \mathrm{CD} 38^{\mathrm{lo}}, \mathrm{CD} 40^{\mathrm{lo}}$, $\mathrm{CD}_{4}{ }^{+}, \mathrm{CD}_{4}{ }^{+}, \mathrm{CD} 2 \mathrm{~L}^{+}, \mathrm{CD} 123^{+}\left(\mathrm{IL}-3 \mathrm{R} \alpha^{+}\right), \mathrm{CD}^{2} 7^{-}$(IL-

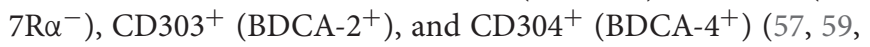
60) The different surface markers, and specific characteristics associated with each dendritic cell type describe above are shown in Figure 1 and in Table $\mathbf{1 .}$

\section{Single-Cell RNA-Seq Approach for the Characterization of Novel DCs Subtypes and Precise DC Ontogeny}

Even though the classical definition of DCs subtypes involves two classes of $\mathrm{CDCs}$ and one class of pDCs, the recent development and more widespread application of single-cell RNA sequencing (scRNA-seq) and cytometry by time-of-flight (CyTOF), have shown that DC subsets can be far more diverse than previously thought. While CyTOF has shown to be useful for the thorough characterization and definition of DC subtypes based on the expression of surface markers, scRNA-seq provides a useful and versatile technique that has allowed to define previously overlooked DC subsets and trace their ontogeny, as well as of other hematopoietic progenitors using transcriptomic data analyses. These approaches have allowed to further characterize several features for each subclass $(91,128-131)$.

For instance, the transcriptomic changes associated with LPS exposure in splenic DCs by scRNA-seq was recently characterized (132). Not only did they find significant differences in gene expression among $\mathrm{cDC} 1 \mathrm{~s}, \mathrm{cDC} 2 \mathrm{~s}$, and $\mathrm{pDCs}$ before and after LPS exposure, but they also found significant and inherent diversity among the classically defined cDC2 subset (132). Thus, they were 


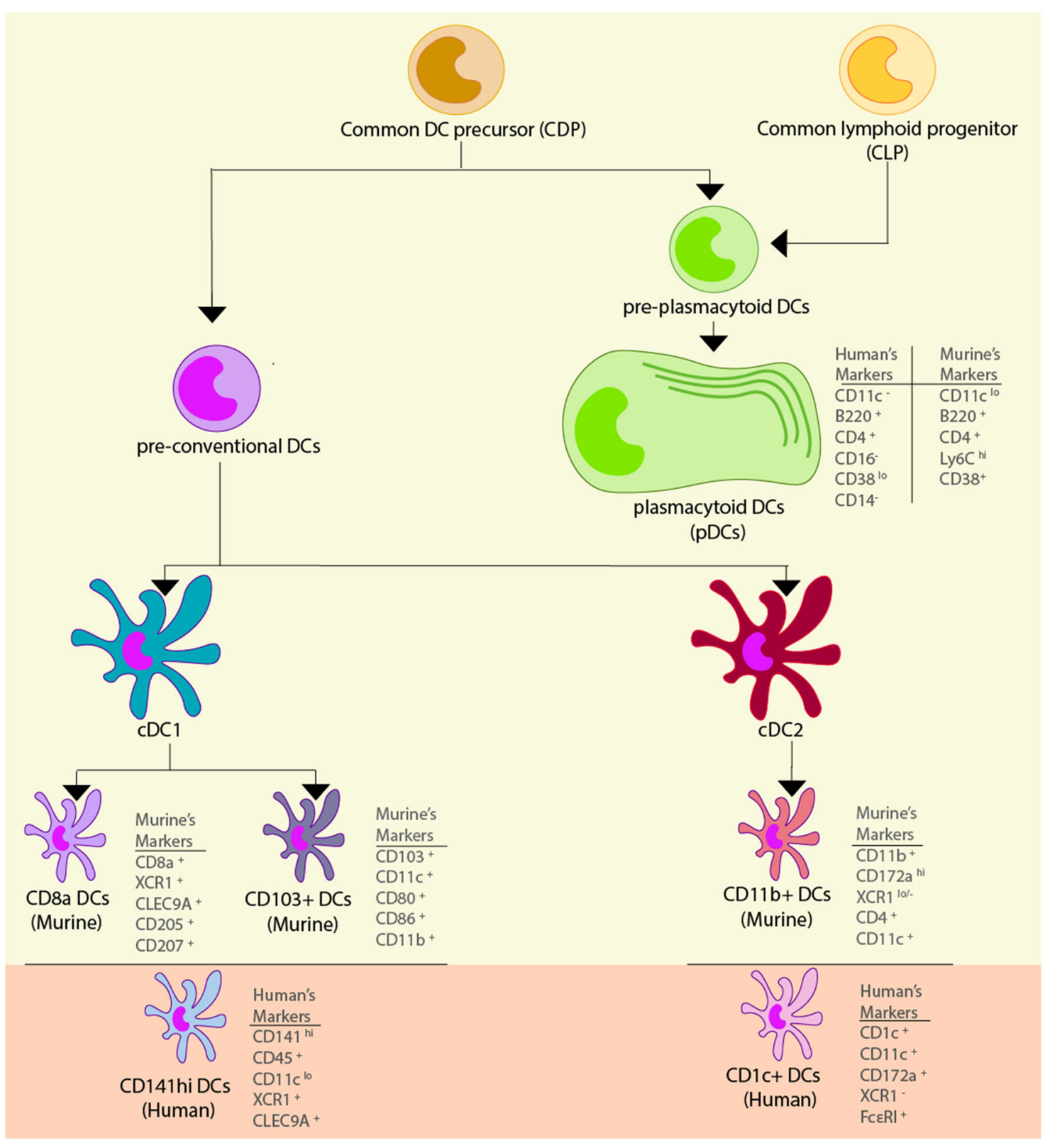

FIGURE 1 | Dendritic cell subsets. Dendritic cells (DCs) are derived from a common myeloid precursor, from which two precursors can be developed. The first precursor corresponds to the pre-conventional DCs and in murine models they can become conventional DCs (CDCs) type 1 and 2, and within these cells there are different subtypes of DCs. In the CDC1 found two subtypes of cells can be found: CD8 ${ }^{+}$DCs which has the markers CD8 ${ }^{+}, \mathrm{XCR}^{+}, \mathrm{CLEC9A}^{+}, \mathrm{CD}_{205}{ }^{+}$, and $\mathrm{CD}_{20}{ }^{+}$, and $\mathrm{CD}_{103^{+}} \mathrm{DCs}$ that has the markers $\mathrm{CD}_{103^{+}}, \mathrm{CD}_{11} \mathrm{c}^{+}, \mathrm{CD} \mathrm{O}^{+}, \mathrm{CD} 6^{+}$, and $\mathrm{CD} 11 \mathrm{~b}^{+}$. The functional homolog of these cells in human are the $\mathrm{CD} 141^{\mathrm{hi}}$ DCs, and their markers correspond to CD141 $1^{\text {hi }}, \mathrm{CD}_{4} 5^{+}, \mathrm{CD} 11 \mathrm{c}^{\mathrm{lo}}, \mathrm{XCR} 1^{+}$, and CLEC9A ${ }^{+}$. In the CDC2 subsets are comprised the CD11 $\mathrm{b}^{+} \mathrm{DCs}$ which has the

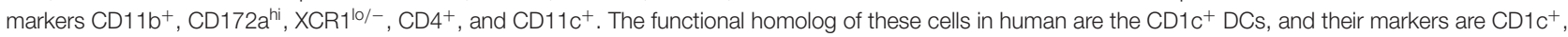

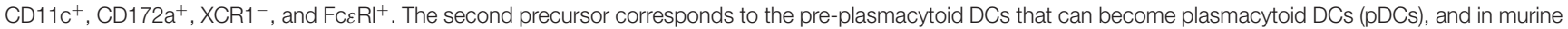
models its markers correspond to $\mathrm{CD} 11^{10}, \mathrm{~B}_{2} 2 \mathrm{O}^{+}, \mathrm{CD}^{+}, \mathrm{Ly}_{6 \mathrm{C}^{\mathrm{hi}}}$, and $\mathrm{CD} 38^{+}$, while in human, their markers correspond to $\mathrm{CD} 11^{-}, \mathrm{B}_{2} 2 \mathrm{O}^{+}, \mathrm{CD} 4^{+}, \mathrm{CD} 11 \mathrm{a}^{+}$, and CD38.

able to identify 4 classes of cDCs, as well as one class of pDCs, by the analysis of transcriptional profile for each cell (132).

Three years later, Villani et al. found 6 classes of DCs in human peripheral blood by FACS sorting, followed by scRNAseq and named them DC1-6 accordingly (133). The DC1 cluster corresponded to classically defined cDC1s (133). The
DC2 and DC3 clusters corresponded to two transcriptomic profiles found to be distinct among classically defined cDC2s, and the DC3 cluster was found to possess an inflammatory gene expression signature (133). The finding of two distinct subclasses of $\mathrm{cDC} 2 \mathrm{~s}$ is not surprising, considering the evidence of functional and transcriptional heterogeneity among this group 
(130, 132, 134). The DC4 cluster corresponded to an MHC$\mathrm{II}^{+}, \mathrm{CD} 11 \mathrm{c}^{+}, \mathrm{CD} 1 \mathrm{c}^{-}, \mathrm{CD} 141^{-}$population, that did not meet neither $\mathrm{cDC} 1, \mathrm{cDC} 2$, nor $\mathrm{pDC}$ inclusion criteria (133). The DC5 cluster was unprecedented and corresponded to $\mathrm{MHC}-\mathrm{II}^{+}$, CD11c ${ }^{-}, \mathrm{CD} 123^{-/+}$DCs. This cluster was characterized by a high expression of AXL and SIGLEC6 and was named AS DCs (133). These cells were found to be in close relation to pDCs (DC6, the last cluster), since they expressed a few similar markers, such as CD123 and CD303. However, they were functionally distinct, since they did not produce IFN- $\alpha$ upon stimulation. Moreover, they secreted IL-12p70 and IL-8, upregulated CD86 upon activation, and were able to prime $\mathrm{T}$ cells, whereas sorted "pure" pDCs -gated excluding AS DCs- did not (133). This is quite remarkable, as previous studies show IL-12p70 secretion, CD80 upregulation, and differences in the expression of the pDC hallmark transcription factor E2-2 among pDCs (135137), a result that could be biased because of the lack of discrimination between pDCs and the newly discovered AS DC subset. Moreover, they could explain some of the heterogeneity observed in this subset (137-139).

The existence of a new class of $\mathrm{cDCs}(\mathrm{cDC} 3)$ was proposed both mice and humans based on their transcriptomic fingerprint using scRNA-seq (140). Interestingly, this new type of DC was discovered in lung tumors of patients and were also found in murine lung carcinomas. Although these cells shared many features with $\mathrm{CDC} 1 \mathrm{~s}$, they lacked the expression of key markers, such as XCR1 and CLEC9A and clustered as an independent group (140). Moreover, cDC3s expressed high levels of transcripts associated with an LPS-activated state defined in a previous study (141). The authors did not find the AS DC subset (DC5 cluster) previosuly described in tumor samples (140). Reciprocally, this last study did not find the cDC3 subset described in blood samples (140). Thes sudies have suggested that this is likely attributed to differences in DC states between blood samples from healthy patients and the tumor environment they analyzed (140).

Lastly, three phenotypic variants for human pDCs where defined after stimulation with the influenza virus, which were named P1, P2, and P3 (142). The definition of these subsets was made based on the expression of CD80 and PD-L1. Different morphologies, as well as distinct surface markers and transcriptomic fingerprints between subsets, were observed (142). Moreover, only cells from the P1 subset $\left(\mathrm{CD} 80^{-}, \mathrm{PD}-\mathrm{L} 1^{+}\right)$ were able to secrete IFN- $\alpha$ in response to virus stimulation and cells of the $\mathrm{P} 3\left(\mathrm{CD} 80^{+}, \mathrm{PD}-\mathrm{L}^{-}\right)$subset had higher migration and $\mathrm{CD} 4^{+} \mathrm{T}$ cell expansion (142). What is interesting about this study is that their gating strategy allowed the sorting of pDCs, while avoiding AS DCs and pre-DC contamination, as previously reported (142). These findings indicate that the observed effects are due to bona fide $\mathrm{pDC}$ subsets, rather than $\mathrm{pDC}$ contamination with other DC subsets (142).

scRNA-seq has also been used to elucidate the intricate network that represents myeloid stem cell differentiation (143145), which has shown to be particularly useful in the field of DC ontogeny. Classically defined human $\mathrm{cDC} 1, \mathrm{cDC} 2$, and $\mathrm{pDC}$ transcriptomic phenotypes are imprinted during ontogeny, rather than by environmental cues in DCs found in blood and secondary lymphoid organs Further, recent studies strongly support the notion that myeloid common DC precursor can give rise to $\mathrm{pDC}$ and pre-DC precursors, from which arise pre-cDC1 and pre-cDC2 progenitors, each committed to maturation toward $\mathrm{CDC} 1$ and $\mathrm{cDC} 2$, respectively $(49,146,147)$. Common upregulated and downregulated genes between pre$\mathrm{CDC1}$ and pre-cDC2, as well as pre-cDC1- and pre-cDC2-specific upregulated genes, and their temporal onset of expression have been determined in mice (147). Moreover, SiglecH and Ly6C can serve as lineage markers during DC development and lineage commitment among pre-DCs occurs in the bone marrow in mice - Siglec $\mathrm{H}^{+}$precursors develop into SiglecH ${ }^{-}$pre-DC precursors, which in turn can be $\mathrm{cDC1}$-committed pre-cDC1s if they are Ly6C ${ }^{-}$, or cDC2-committed pre-cDC2s if they are Ly6C ${ }^{+}$(147).

Altogether, these results suggest that we should rethink the current classification of DCs and then evaluate a more thorough definition of DC subtypes in future studies, considering the possible contamination between subsets that could occur [e.g., pre-DCs and pDCs in mice (146), or AS DCs and pDCs in humans (133)]. Undoubtedly, scRNA-seq, as well as CyTOF, are powerful tools that will continue to unravel the immunobiology of DCs.

\section{IMPORTANCE OF INTERFERON REGULATION FOR THE IMMUNE RESPONSE AGAINST VIRAL INFECTIONS}

IFN is a characteristic antiviral cytokine able to modulate the innate and adaptive immune response (148). This cytokine was discovered in the 1950s (149) and is divided into three different groups: Type I, II, and III IFN, whose function is regulated by the JAK-STAT pathway (150). In humans, type I IFN is divided into IFN- $\alpha$, IFN- $\beta$, IFN- $\varepsilon$, IFN- $\kappa$, IFN- $\omega$; type II into IFN- $\gamma$; and type III into IFN- $\lambda$, which is divided in IFN- $\lambda 1$, IFN- $\lambda 2$, IFN- $\lambda 3$, IFN$\lambda 4(151,152)$. Similarly to humans, in mice, IFNs are divided into three groups-type I IFN includes IFN- $\alpha$, IFN- $\beta$, IFN- $\varepsilon$, IFN- $\kappa$ $(153,154)$, type II comprises IFN- $\gamma$, and type III considers IFN- $\lambda$.

Type I IFN is secreted in response to viral infections when PRRs identify viral proteins or genetic materials, triggering the IFN secretion $(155,156)$. The IFN secreted is later recognized by the IFNAR receptor into the surface of infected cells, promoting the activation of the JAK-STAT pathway. The activation of these pathways starts with the phosphorylation of IFNAR by two enzymes, Janus Kinase 1 (JAK1) and Tyrosine Kinase 2 (TYK2). This phosphorylation modulates the activation of both STAT1 and STAT2, through their phosphorylation and later heterodimerization. This phosphorylated STAT1/STAT2 complex interacts with IRF9 to make the ISGF3 complex that is translocated to the nucleus. Once this complex is in the nucleus, it binds to the DNA sequence where it can activate the IFN-stimulated response elements (ISREs), some antiviral genes and the expression of IFN stimulated genes (ISGs), which are essential to promote the antiviral response in the host (157-161) (Figure 2).

Additionally, two other pathways can be activated when IFN is recognized by IFNAR. The first is triggered by 


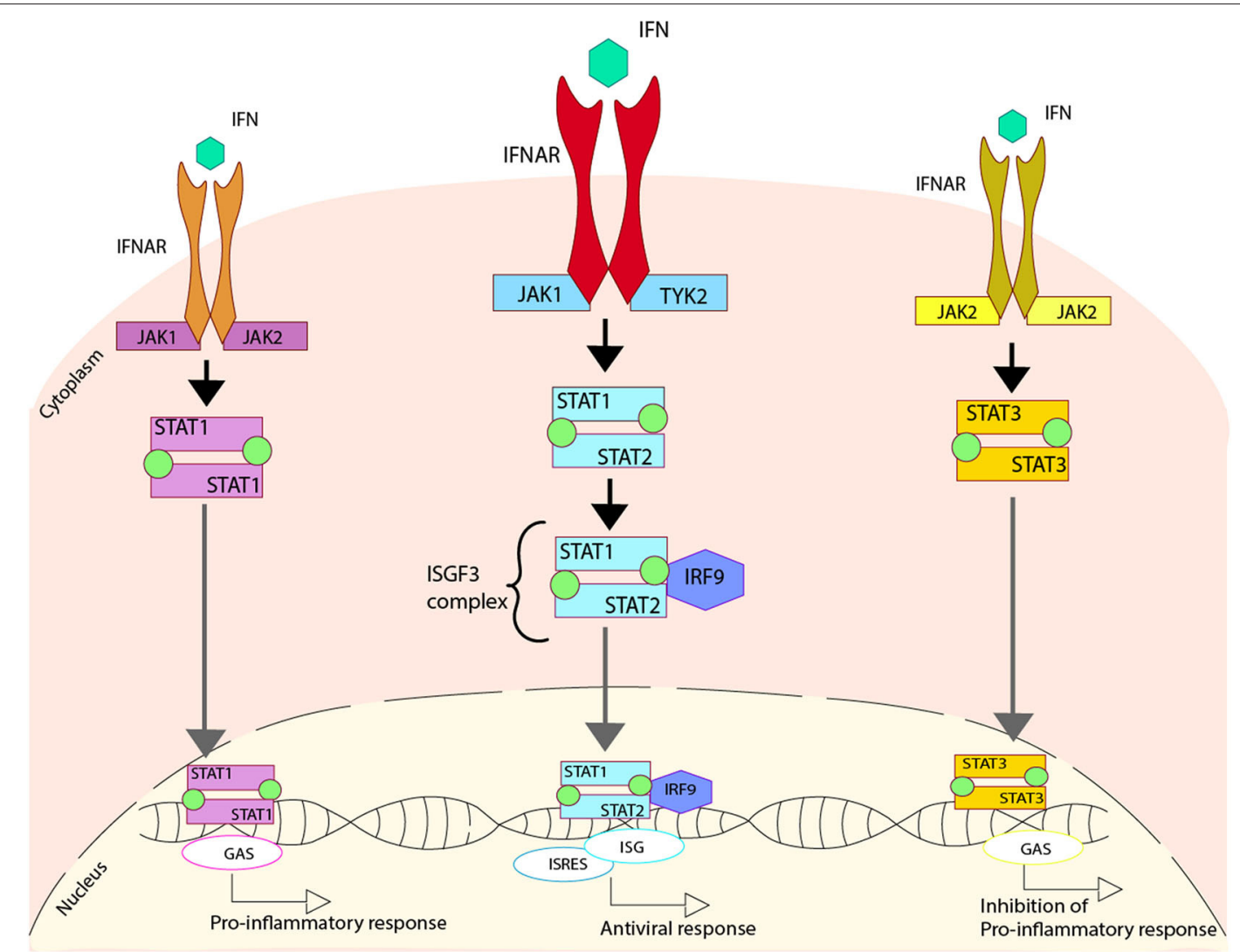

FIGURE 2 | Regulation of type I IFN due to the activation of IFN receptors. Upon activation of the IFNAR receptor induced by the cytokine IFN, three different pathways can be activated. One pathway involves the phosphorylation of the IFNAR cause by Janus Kinase 1 (JAK1) and Tyrosine Kinase 2 (TYK2), which generates the phosphorylation of both STAT1 and STAT2 that come together to form a heterodimer. This heterodimer interacts with IRF9, forming the ISGF3 complex that is translocated to the nucleus where it binds to DNA activating the regions of ISG and ISRES, promoting an antiviral response. An alternative pathway involves the phosphorylation of the IFNAR caused by JAK1 and JAK2, which produces the phosphorylation of STAT1 and two of them come together in order to form a homodimer. This homodimer is able to translocate to the nucleus where it binds to DNA, activating the regions of GAS, and promoting a pro-inflammatory response. Another alternative pathway involves the phosphorylation of the IFNAR, caused by JAK2, which generates the phosphorylation of STAT3, and two of these come together in order to form a homodimer. This homodimer is able to translocate to the nucleus where it binds to DNA, activating the regions of GAS and promoting the inhibition of the pro-inflammatory response.

the homodimerization of the phosphorylated STAT1 that is translocated into the nucleus and recognizes the gammaactivated sequence (GAS) within the DNA, activating a proinflammatory response (162). The other pathway is triggered by the homodimerization of the phosphorylated STAT3, which is translocated to the nucleus, where it is also able to recognize GAS. This interaction promotes the inhibition of the pro-inflammatory response, probably by an unknown self-control system able to sense the damage $(163,164)$ (Figure 2).

Another pathway described to promote an antiviral immune response associated with type I IFN response is through the activation of different Toll-like receptors (TLR) (165-167). TLR7 is activated by guanosine/uridine-rich ssRNA from viruses (168-170), while TLR9 is characterized by the recognition of methylated CpG rich DNA (171). However, both TLR7 and TLR9 trigger a common pathway mediated by MYD88 (167). Specifically, TLR9 can promote IFN- $\alpha$ or IFN- $\beta$, depending on the type of dendritic cells and their stimuli. In plasmacytoid DCs
(pDCs), TLR9 recognizes type A CpG oligonucleotides (CpGA) promoting the binding of MYD88 that later interacts with TRAF6 triggering IRF7 activation. This activation of IRF7 is dependent on the ubiquitin E3 ligase activity of TRAF6. Once IRF7 is activated, it can phosphorylate independently of TBK1/IKK, and it can be translocated into the nucleus to promote the activation of the type I IFN- $\alpha / \beta$ (172-175). Additionally, TLR9 can recognize type $\mathrm{B} C \mathrm{pG}$ oligonucleotides (CpGB) in pDCs, stimulating the maturation of this cell type but inducing low levels of IFN- $\alpha$ (176). On the other hand, in cDCs and other cell types -such as macrophages-, TLR9 recognizes CPGB promoting the binding of MYD88 and the later interaction with IRF1, which is translocated into the nucleus to promote the activation of the only type I IFN- $\beta$ (173). This pathway, unlike the one described above for pDCs, does not require the use of IRF3 or IRF7 (173) (Figure 3).

Another typical TLR associated with the antiviral response is TLR3, which is found in endosomes of cDCs and is 


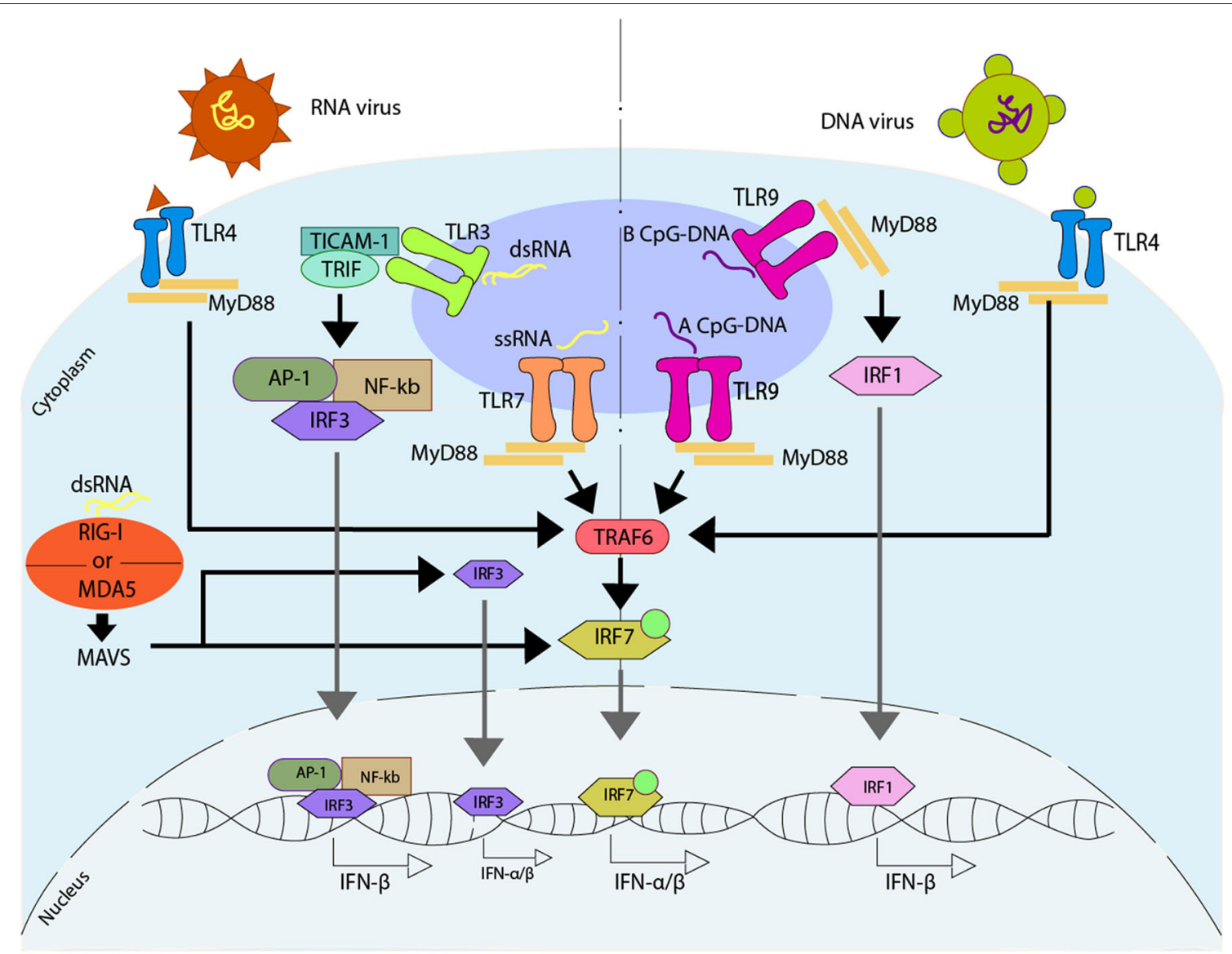

FIGURE 3 | Regulation of type I IFN due to the activation of Toll-like receptors. Upon activation of Toll-like receptor (TLR) induced directly by viruses, different pathways can be activated. TLR7 recognize ssRNA, promoting the binding with MYD88, that will later interact with TRAF6, activating IRF7 which is translocated to the nucleus where it binds to DNA, promoting the release of IFN- $\alpha / \beta$. TLR3 recognize dsRNA, promoting the interaction with TICAM-1 and TRIF, that activates AP-1,

$\mathrm{NF}-\mathrm{kB}$, and IRF3, which are translocated to the nucleus, where they bind to DNA, promoting the release of IFN- $\beta$. The dsRNA can activate an alternative pathway, which can be sensed by either retinoic acid-inducible gene I (RIG-I) or by melanoma differentiation-associated protein 5 (MDA5). These receptors activate mitochondrial antiviral-signaling protein (MAVS), and by doing so they promote the IRF3 and/or IRF7 activation, and later translocation into the nucleus where they bind to DNA, promoting the release of IFN- $\alpha / \beta$. There are two ways of activating TLR9, one is through the recognition of a type A CpG-DNA, which activates the pathway mediated by MYD88, similar to TLR7, while the other one involves the recognition of a type B CpG-DNA, where TLR9 binds with MYD88, activating IRF1, which is then translocated into the nucleus where it binds to DNA promoting the release of IFN- $\beta$. On the other hand, TLR4 is able to recognize viral peptides, activating a MYD88 -depending pathway similar to TLR7.

capable of recognizing dsRNA (177). Once it identifies the dsRNA, TLR3 interacts with the adaptor protein TIR-containing adaptor molecule-1 (TICAM-1/TRIF). This interaction promotes the activation of AP-1, IRF3, and NF- $\kappa$ B, which then are translocated into the nucleus to promote the expression of IFN$\beta$. Additionally, the activation of the NF- $\kappa \mathrm{B}$ pathway allows the expression of pro-inflammatory genes (178-180).

Finally, TLR4, who is localized in the surface of cells, is able to identify different viral proteins, triggering the signaling and activation of type I IFN genes through the MYD88 pathway (181). Additionally, TLR4 can modulate the activation of type I IFN genes through other ways associated with TRIF, where TLR4 interacts with TRIF through TRAM, triggering a late activation of the MYD88 pathway, and the expression of type I IFN genes against viral infection $(182,183)$ (Figure 3). Similar to TLR4, TLR2 -which is also localized in the surface of the cells- has also been associated with the identification of viral proteins (184).

\section{ANTIVIRAL ACTIVITY OF DCs AGAINST RNA VIRUSES}

As was mentioned above, DCs subsets are crucial players in the host defense against pathogens, particularly viruses. In this section, we will discuss the antiviral role of DCs against RNA viruses that we consider epidemiologically relevant and elicit a well-described antiviral activity of DCs, such as the human respiratory syncytial virus, the human metapneumovirus, Influenza virus, the hepatitis $C$ virus, and the human immunodeficiency virus. The different PAMPs from each virus are mentioned in Table 2. 
TABLE 2 | Viruses and some of their PAMPs.

\begin{tabular}{|c|c|c|c|}
\hline Type of virus & Virus & PAMPs & References \\
\hline \multirow[t]{5}{*}{ RNA genome } & $\begin{array}{l}\text { Human respiratory } \\
\text { syncytial virus }\end{array}$ & $\begin{array}{l}\text { (-)ssRNA } \\
\text { Nucleoprotein (N) }\end{array}$ & $(185-187)$ \\
\hline & $\begin{array}{l}\text { Human } \\
\text { metapneumovirus }\end{array}$ & $\begin{array}{l}\text { (-)ssRNA } \\
\text { Glycoprotein (G) }\end{array}$ & $(188-190)$ \\
\hline & Influenza virus & $\begin{array}{l}(-) \text { ssRNA } \\
\text { Hemagglutinin (HA) } \\
\text { Neuraminidase (NA) }\end{array}$ & $(191-193)$ \\
\hline & Hepatitis C virus & $\begin{array}{l}(+) \text { ssRNA } \\
\text { Non-structural (NS)3 } \\
\text { Non-structural (NS)4A } \\
\text { Non-structural (NS)5 }\end{array}$ & $(194-197)$ \\
\hline & $\begin{array}{l}\text { Human } \\
\text { immunodeficiency virus }\end{array}$ & $(+)$ ssRNA & $(198,199)$ \\
\hline \multirow[t]{6}{*}{ DNA genome } & Papillomavirus & $\begin{array}{l}\text { dsDNA } \\
\text { E6 protein } \\
\text { E7 protein }\end{array}$ & (200-203) \\
\hline & Adenovirus & DNA & (204) \\
\hline & Hepatitis B virus & DNA & $(205,206)$ \\
\hline & Human alphaherpvirus & $\begin{array}{l}\text { DNA } \\
\text { US11 proteins }\end{array}$ & (205-207) \\
\hline & $\begin{array}{l}\text { Human } \\
\text { alphaherpesvirus } 3\end{array}$ & DNA & (208) \\
\hline & $\begin{array}{l}\text { Human } \\
\text { gammaherspesvirus } 4\end{array}$ & dsDNA & (209) \\
\hline
\end{tabular}

\section{Human Respiratory Syncytial Virus}

Human respiratory syncytial virus (hRSV) is an enveloped member of the Pneumoviridae family, which has a singlestranded negative-sensed RNA genome $(185,186)$. The disease caused by hRSV is characterized mainly by the infiltration of eosinophils and neutrophils into the airways. An increase infiltration of neutrophils can contribute to lung damage (210212). Even though $\mathrm{CD}^{+} \mathrm{T}$ cells are key in the clearance of the virus, it has been reported that the depletion of the $\mathrm{CD}^{+}$and $\mathrm{CD}^{+}{ }^{+} \mathrm{T}$ cells in mice decreased the severity of the illness (213-215).

As expected, the antiviral immune response against hRSV is commanded by DCs. The different subsets of DCs in the lung play a specific role in the antiviral immune response against this virus. The pDCs are susceptible to hRSV infection in humans (127) and mice (216), increasing the expression of molecular surface markers such as CD80, CD86, and CD40, indicating the maturation of these cells (217). Interestingly, a report indicated that upon infection with hRSV, the amount of pDCs was less in preterm infants as compared to those born at term (218). Studies in human monocyte-derived DCs (moDCs) and pDCs showed that both subsets of DCs could be infected by hRSV, and their infection promotes the secretion of several cytokines such as IL-6, IL-10, TNF- $\alpha$, IL-1 $\beta$, and IL-12p70 (24). One of the differences of the effect of hRSV infection is that the induction of IFN- $\alpha$ was detected only in pDCs, and this infection can inhibit the production of type I IFN in cDCs and pDCs through the recognition of TLRs agonist $(24,219)$. However, the absence of
pDCs does not alter the levels of IFN- $\alpha$ during the infection with hRSV (220).

In a murine model, Smit et al. described that the number of cDCs and pDCs were increased in the lung and also, in the lungdraining lymph nodes of $\mathrm{BALB} / \mathrm{c} \mathrm{hRSV}$-infected mice during the acute phase of the infection (221). Moreover, when pDCs were depleted, the immunopathology caused by hRSV was enhanced in the lung of infected mice, as seen by an increase in the viral loads. This result demonstrated that $\mathrm{pDCs}$ are relevant during hRSV clearance (221). According to this, in the absence of pDCs, the levels of IFN- $\alpha$ were drastically decreased, consistently with previous reports $(216,221,222)$.

Moreover, it has been described that hRSV infection of cDCs does not alter the expression of maturation surface markers in adult mice. However, in neonates, the CD80 and CD86 maturation markers are decreased (223). These findings are in accordance with the severity of the immunopathology described in neonatal and adults mice models (223). As APCs, cDCs are important in the activation of $\mathrm{T}$ cells, but this essential function is altered by hRSV infection (224). Interestingly, hRSV infection on cDCs impairs the immunological synapses mediated by the surface expression of the hRSV nucleoprotein $(187,224)$. This impairment can explain why the host displays an inefficient immune response against hRSV and why the host can be reinfected by this virus throughout its life.

\section{hMPV}

The human metapneumovirus (hMPV) also belongs to the Pneumoviridae family, and it has a single-stranded RNA genome with a negative sense (188). This virus is globally recognized as the second most important agent that causes bronchiolitis and pneumonia in susceptible individuals (225). Noteworthily, the mechanisms by which hMPV can evade the establishment of an appropriate immune response are still poorly characterized in humans, but recent studies in BALB/c mice suggest that infiltrating $\mathrm{T}$ cells play a pathogenic role during $\mathrm{hMPV}$ infection $(226,227)$.

It has been described that DCs are susceptible to be infected by hMPV and, depending on the strain and the host, the replication in these cells can be productive or abortive in an in vitro model of human cDCs (228) or mouse bone-marrow-derived DCs (BMDCs) (229), respectively. Moreover, hMPV can infect both human moDCs and pDCs, which promote the maturation of the cells (24). Furthermore, in hMPV-infected DCs, the production of IFN- $\alpha$ is increased, but this effect is inhibited in response to TLR agonists (24). Compared to hRSV, hMPV is more susceptible to the antiviral effect of IFN- $\alpha$. This observation can be explained by the lack of NS1 and NS2 proteins in hMPV, present in hRSV, that have been described to interfere with the type I IFN signaling (230).

The infection of DCs by hMPV also impairs the ability of these cells to establish an efficient immunological synapse that allows $\mathrm{T}$ cell activation (229). One of the most important virulence factors of hMPV is the G glycoprotein $(189,190,231)$. This protein has a role in the inhibition of the TLR4-depending signaling in moDCs. Kolli et al. demonstrate that human hMPV-infected moDCs downregulate the expression of the TLR4. Moreover, 
when evaluating DCs obtained from a mouse with a silenced TLR4 and infected with hMPV, the cytokines induced by the infection, such as IL-6, IL-10, CCL5, and IFN- $\beta$, were also decreased (190). Besides, to demonstrate the role of the GhMPV glycoprotein, the authors tested a recombinant hMPV$\triangle G$ virus. The data showed that, in the absence of the G-hMPV glycoprotein, there was increased production of cytokines and a moderate change in the IFN type I expression $(190,231)$. According to these results, TLR4 plays an important role in the activation of DCs during an hMPV infection.

\section{Influenza Virus}

Influenza virus (IV) belongs to the Orthomyxoviradae family, with a negative-sensed, single-stranded, and segmented RNA genome $(191,192)$. This virus can be classified into types A, $\mathrm{B}, \mathrm{C}$, and $\mathrm{D}$, being the influenza $\mathrm{A}$ virus (IAV), the most prevalent and responsible for the pandemics $(192,232)$. In the viral surface, the major glycoproteins are the hemagglutinin (HA) and neuraminidase (NA), being these proteins the basis of the classification of the IVs subtypes such as H1N1, H2N3, and H7N9, among others (193). As hRSV and hMPV, IAV also infects humans (233) and murine (234) DCs, although this infection is lower in murine DCs, and its infectivity depends on the type of HA protein in the virus (234). In the case of human DCs, the cDCs are more susceptible to the IAV infection than pDCs,and, in this context, the IAV-infected cDCs are less efficient to activate $\mathrm{CD}^{+}$T cells (233).

During IAV infection, DCs are one of the most relevant cell types in the initiation of the host immune response. It has been described that the recombinant HA proteins from A/WSN/33 (H1N1) and A/Thailand/KAN-1/2004 (H5N1) can induce cDCs maturation, and therefore the production of cytokines such as TNF- $\alpha$ and IL-12p70 (235). Also, TLRs on DCs are relevant for the recognition of IAV infection. The $\mathrm{cDCs}$ ' activation occurs via TLR3 and TLR9 signaling $(235,236)$, whereas the activation of pDCs is via TLR7 (237) (Figure 3).

\section{Hepatitis C Virus}

Hepatitis C virus (HCV) is part of the Flaviviruses family and presents a positive-sensed, single-stranded RNA genome (194). The prevalence of $\mathrm{HCV}$ represents a $2.2 \%$ infected subjects worldwide, and it is known for causing hepatitis to a chronic level that can even lead to hepatocellular carcinoma $(195,238,239)$. Two potential antiviral targets are the nonstructural (NS) protein 3, which has a helicase and protease activity, and NS5, which has an RNA-dependent RNA polymerase activity. However, the peculiarity of this virus allows it to mutate frequently and generates up to six different genotypes (195). Even though hepatocytes are its principal target cell, it has been found that this virus can infect DCs at a minor level, interfering with its capacity to stimulate allogeneic $\mathrm{T}$ cells and to secrete IFN- $\gamma$ (238, 240, 241).

$\mathrm{HCV}$ can evade the antiviral response due to the activity of the NS3/4A protease, which can inhibit the RIG-1 pathway, and the pathway where the TRIF protein participates $(196,197)$. It has been reported that when HCV infects hepatocytes, it can inhibit type I IFN secretion. However, evidence suggests that there are other cells in the liver capable of stimulating the ISG, during infection with this virus (242-244). Within a liver infected by $\mathrm{HCV}$, pDCs are found in great numbers, even though the infection with this virus can decrease the number of $\mathrm{pDCs}$ and inhibit their function (245-247). It seems that through cell-to-cell contact between the cells infected with HCV and pDCs, the latter can secrete type I IFN as a result of the signal produce by TLR7, due to the sensing of the RNA of the virus, without infecting pDCs directly (243).

\section{Human Immunodeficiency Virus}

The human immunodeficiency virus (HIV) belongs to the Retroviridae family and has two positive-sensed and singlestranded RNA molecules $(198,199)$. This virus is divided into two types, HIV-1 and HIV-2, where HIV-1 is the one described as a pandemic affecting $\sim 37$ million people (248-250). The progression of the disease due to the continuous activation of the immune system and the low levels of $\mathrm{CD}^{+}{ }^{+} \mathrm{T}$ cells can lead to the development of the acquired immunodeficiency syndrome (AIDS) $(251,252)$. Studies in vitro with human DCs have demonstrated that some of these cells are susceptible to the infection with HIV, such as Langerhans cells, cDCs, and pDCs $(253,254)$. Interestedly, cDCs from HIV patients have shown low levels in the blood, and their function is compromised (255). When HIV infects DCs, it can travel within the cell until it locates memory $\mathrm{CD}^{+} \mathrm{T}$ cells into the lymphoid tissue, spreading the infection in this way $(256,257)$. Langerhans cells are the first cells that interact with HIV, and studies in these types of cells have demonstrated that Langerin receptors can block the transmission of the virus, making it possible to avoid the infection (258). Upon the HIV-infection of cDCs, the anti-viral pathways within these cells are changed, and as a result, it promotes the viral spreading. However, the use of antiretroviral therapies (ART) can return completely the functionality of the pathways IL-1 and type I IFN (255, 259).

The HIV ssRNA is recognized by TLR7, stimulating the MYD88 pathway to activate IRF7 in pDCs $(260,261)$. The secretion of IFN- $\alpha$ promotes the expression of the HIV restriction factor through the stimulation of IFNAR, thus inducing the activation of the JAK1/TYK2 pathway (262). The activation of $\mathrm{pDCs}$ is desirable to stimulate the production of IFN- $\alpha / \beta$ since it can control the spreading of the virus, but the continuous secretion of this cytokine can cause more damage than benefit $(263,264)$. The negative effect of a continuous induction of type I IFN involves the chronic activation of the immune system, immunosuppressive pathways are activated, and immunopathogenesis, along with immunodeficient syndromes are detected (264). Even though pDCs are no the main source of IFNs during HIV-infection, these cells play an important role during the infection due to the capability to target infected-cells and, at the same time, promote the immunopathogenesis (265). Even more, as a consequence of the constant activation of pDCs and the immune system, the chances of developing AIDS are increased $(266,267)$. There is an alternative pathway by which TLR7 is able to activate NF- $\mathrm{B}$, which can trigger the production of type I IFN as well $(261,268)$. Even though pDCs have two different pathways that promote the secretion of type I IFN, the 
amount of IFN secreted is lower compared to LPS-stimulated DCs (269).

\section{ANTIVIRAL ACTIVITY OF DCs AGAINST DNA VIRUSES}

The role of DCs during DNA virus infections have also been characterized -thoroughly or partially, depending on the pathogen. In this line, infections and diseases caused by Papillomavirus, Adenovirus, hepatitis B virus, and Herpesvirus will be discussed in the following section, as DNA viruses that are considered to be epidemic viruses. Accordingly, these viruses have been described as epidemiologically relevant, since they cause several diseases with high incidences worldwide. The different PAMPs from each virus are mentioned in Table 2.

\section{Papillomavirus}

Human papillomavirus (HPV) is a dsDNA virus recognized as the main etiological agent of cervical cancer, and it is also associated with carcinomas of the vulva, vagina, anus, and penis (200-202). However, infection with this virus can lead to several pathologies, such as cutaneous warts, squamous intraepithelial lesions, and even respiratory papillomatosis $(200,201)$. In this line, HPV exhibits a tropism for cutaneous and mucosal epithelial cells -without inducing the destruction of the infected cells-, thus explaining the type of carcinomas that it can cause (200). Remarkably, there are over 200 different species of HPV, divided into five different groups -alpha, beta, gamma, mu, and nuand they are categorized according to their tropism and genetic composition $(202,270)$. The alpha group is the most studied and characterized so far, with HPV species in this subset dived as high or low risk (201).

Since immune surveillance is crucial for the establishment of persistence and the appearance of skins lesions, and epithelial cells -particularly keratinocytes- are the main target of infection for this virus, the DCs subtype that will play a more critical role in the regulation of this infection are Langerhans cells (LCs) (271-273). Remarkably, infection of LCs with HPV results in no expression of the genes of this virus, therefore being non-productive $(271,272)$. In light of this, cross-presentation performed by LCs is a fundamental step for the activation of $\mathrm{T}$ cells, once the former reaches the $\mathrm{LN}$, during infection with HPV (274). A down-regulation of MHC-I has been reported during cervical carcinomas in human studies, which has also been associated with HPV-related carcinoma (275). This suggests that there is a decrease in the achievement of a proper $\mathrm{T}$ cell activation in this HPV-associated cancer, which, along with its immune evasion-associated capacities, makes this virus more virulent.

Upon infection, keratinocytes will secrete several proinflammatory cytokines that will induce the recruitment and activation of LCs (276-278). Recognition of HPV by DCs will induce their activation and eventual maturation (271273). However, keratinocytes have also been reported to secrete anti-inflammatory molecules -such as TGF- $\beta$ and IL-10- upon infection with HPV and once the tumor has been established, therefore down-modulating the activation of LCs (277). This results in an increased capacity for immune evasion for this virus. In this line, it has also been described that TLR3, TLR5, TLR8, and TLR9 pathways are activated during HPV infections (203, 278-280). However, two proteins of HPV (E6 and E7) have been described to down-modulate TLR9 expression -and IFN synthesis along with it-, once again favoring its immune evasion capabilities (203). Remarkably, overexpression of TLR4 has been described in HPV-infected cells, and this is correlated with resistance to apoptosis in these infected cells (280).

DCs -particularly LCs- will also play a significant role during cervical cancer that may induce HPV (272). As expected, immature LCs will sense their environment, capture and process antigens, and migrate to their respective LN. However, several studies have shown that, during HPV infections, these cells exhibit an impaired phenotype (281-286). For instance, lower numbers and frequencies of LCs (281-283), changes in their morphological characteristics (284), and decreased capacities to induce a proper immune response have been reported in this context $(286,287)$. In light of all this, the critical role that LCs play during infections, and the persistence of HPV infection is more than evident. Therefore, further studies and insights in the role of these cells during this disease are mandatory to elucidate and suggest new approaches for its treatment.

\section{Adenovirus}

Adenovirus (AdV) are non-enveloped viruses responsible for diseases associated with the upper and lower respiratory tract, reaching even the gastrointestinal tract and the conjunctiva and cornea, depending on the species of the AdV and the immune condition of the host (288). Considering all this, it is important to describe how the innate immune response, and particularly DCs, are capable of detecting and responding once AdV reaches an organism, although the mechanisms associated with this are not completely well understood.

AdV targets of infection are both dividing and quiescent cells, with specific tropism associated with the species of the virus (289). In this line, DCs can be transformed with AdV, with entry mechanisms that differ from those of epithelial cells, and with the capability of being modulated by cytokines and chemokines (288-290). Remarkably, it has been described that AdV is capable of inducing maturation of DCs strongly upon encounter (290, 291). Moreover, studies indicate that AdV presented as immunocomplexes to DCs can induce pyroptosis -a type of apoptosis associated with the formation of the inflammasomein these cells (291).

It has been described that AdV can be recognized by TLR2, TLR4, and TLR9 (292-295). Engagement of TLR2 during AdV has been shown to be necessary for the activation of NF- $\kappa B$ and the mount of an effective humoral response, as $\mathrm{KO}$ mice for these receptors show deficiencies in these responses (294). Accordingly, TLR4 activation -by AdV complexes- leads to the IL- $1 \beta$-associated inflammatory response, possibly modulating the formation of the inflammasome that will induce pyroptosis (295). Finally, the recognition of TLR9 in PBMCs and pDCs leads to the secretion of many pro-inflammatory cytokines and the activation of the type I IFN pathway $(292,293)$. Since all these receptors require the adaptor protein MYD88 to properly 
signalize, the upregulation of this protein has been described upon infection $(296,297)$. Besides these TLRs, AdV can also be recognized by other PRRs, such as Lectin receptors -for instance, Siglecs and Galectins $(298,299)$ - and inflammasome-associated DNA sensings receptors -such as NLRs AIM2 and NALP3 for $\operatorname{AdV}$ (300, 301). Activation of all these receptors will induce maturation and activation of DCs, leading to the mounting of a classical antiviral response. However, further studies are required to properly elicit the role of DCs in the infection of this virus.

\section{Hepatitis B Virus}

Hepatitis B virus (HBV) is the etiological agent responsible for either a self-limiting or a chronic infection that affects the hepatocytes in the liver of over 250 million people worldwide $(302,303)$. The disease caused by this virus is characterized by an inadequate immune response and, in the long-term, the development of hepatitis, cirrhosis, and hepatocellular carcinoma (302). The interaction between this virus and the immune system is both innate- and adaptive-related, although the role of the latter has been more thoroughly described than the former (194, 207, 302). Accordingly, the adaptive immune response seems to play a more significant role in the modulation of chronic infection $(194,207,302)$. In this point, DCs are fundamental since they work as the bridge between the innate and the adaptive response.

HBV induces an inefficient innate immune response -and also an impaired activation of DCs-, due to several of its characteristics and its infectious cycle (207). For instance, most of its DNA is recognized just as host genetic material -therefore not triggering an immune response-, although certain conformations of the HBV's DNA may be recognized by RIG-I or TLR9, as described by some authors (205-207). Accordingly, acute exposure of this virus does not induce the secretion of IFN or pro-inflammatory cytokines by either pDCs (the responsible for secreting type I IFN) or other immune cells, therefore not mounting the first line of defense against viral infection (207, 304). Even so, increased secretion of IL-10 upon infection has been reported, which could explain the lack of response described for this virus, as this cytokine will induce a state of tolerance in the surveilling immune cells $(305,306)$. Remarkably, since it has been described that pDCs from $\mathrm{HBV}$ infected patients are impaired in their capacities to secrete IFN, this also results in a decreased capacity to induce the proper activation of NK cells $(302,307)$.

Recognition of PAMPs derived from HBV by PRRs -and therefore the innate immune system and DCs- is currently a controversial field, as in vitro studies of HBV are hard to perform. These difficulties are associated with the high multiplicity of infection (MOI) required to achieve a productive infection in human primary hepatocytes (308). Moreover, several other factors difficult in vitro studies with this virus, such as an inadequate capacity of this virus to diffuse in monolayers (308), the differences in the inoculum used, and the generation of artifactual results obtained from all these points (207, 308). Despite all this, it has been suggested that the nucleocapsid of this virus may act as a TLR2 ligand, leading to the secretion of several pro-inflammatory cytokines $(309,310)$. Also, Vanlandschoot et al. reported that subviral particles might be recognized by one of the co-receptors of TLR4, inducing the activation of myeloid cells $(311,312)$. Therefore, more studies are required to elicit further the role of DCs and the innate response during an HBV infection.

A study performed recently by Yonejima et al. analyzed the gene expression and function of DCs in a cohort of 64 humans infected with HBV (313). In this article, the authors show that there are no differences in the number of circulating DCs in the PBMCs samples of the subjects, as previously reported for HBV infected patients $(314,315)$. Accordingly, no differences in the levels of expression of CD80, CD83, CD40, and CCR7 were found in the $\mathrm{CDCs}$ subset analyzed. However, DCs obtained from these patients exhibited impaired antigen-presenting capacities, a decrease in their capacities to migrate, and impaired levels of cytokine production, as seen during in vitro assays. Other studies have also shown similar results, still supporting the notion that HBV induces a tolerogenic state $(316,317)$. By performing microarray assays, the authors also suggest that one of the genes responsible for this impairment is the IL-6 signal transducer (IL6ST), since rescuing the proper expression levels of this gene resulted in the recovery of the previously indicated function of DCs. Thus, IL6ST may constitute a possible therapeutic target to treat HBV infection (313).

Indeed, DCs seems to play a pivotal role during the selflimiting and the chronic disease caused by HBV, but further researches are required in order to thoroughly comprehend the magnitude of these cells in this disease.

\section{Herpesvirus}

The order Herpesvirales comprises many species of herpesviruses, among which we can highlight the human alphaherpesvirus 1 and 2 -commonly known as human herpes simplex virus 1 and 2 (HSV-1 and HSV-2)-, the human alphaherpesvirus 3 -commonly known as varicella-zoster virus (VZV)- and the human gammaherpesvirus 4 -commonly known as EpsteinBarr virus (EBV) (318). All these viruses, among others of the same order, are responsible for different diseases in humans, with symptoms ranging from blisters to severe neurological alterations (319).

As stated above, human alphaherpesvirus comprises HSV1 and HSV-2. Upon HSV infection, and as expected for most viruses, the type I IFN pathway is activated, leading to the secretion of IFN- $\alpha$ and IFN- $\beta(320,321)$. This activation is mediated by PRRs that can recognize HSV, such as TLR3 and TLR9, which will be activated in the presence of viral-related genetic material. Moreover, TLR2 and TLR4 have also been described to be activated upon HSV infection (322). RIG-I will detect viral-related genetic material -particularly dsRNA- and induce the production of type I IFN and other proinflammatory cytokines (321). Remarkably, it has been described that US11, an HSV-1 tegument protein, is capable of inhibiting the antiviral protein elicited upon RIG-I activation by degrading downstream signals of this pathway (323). Since most of these PRRs are expressed in DCs, they are relevant in their role for the modulation of this infection. Remarkably, HSV-1 is capable of infecting DCs, and HSV-infected DCs are not capable of achieving maturation (324). Despite this, HSV-infected and 
non-matured DCs are capable of secreting proinflammatory cytokines, which will help other DCs to achieve maturation if they are not infected (324). Once matured, DCs will be able to internalize the virus, either as a free particle or by phagocyting other infected cells -even infected DCs-, degrade it, and eventually cross-present it to the adaptive immune system, which will initiate a new response $(321,324)$. Furthermore, depletion of the IgD glycoprotein in HVS-2 has been found to promote efficient activation of DCs and effective activation of $\mathrm{CD}^{+}$and $\mathrm{CD} 8^{+} \mathrm{T}$ cells (325).

The main target of infection and replication of human alphaherpesvirus 3 or VZV are epithelial cells of the respiratory tract. Initial viral replication will eventually lead to viremia and the characteristic rash -commonly known as chickenpox- that is particular for the disease caused by this virus (326). Upon resolution of this stage, the virus achieves latency in the nerve cells that innervate the portions of skin affected with the rash (326). In order to be reactivated, the virus must be mobilized by anterograde transport into the skin cells. As seen for HSV, DCs in the skin can be infected by VZV -as reported in ex vivo experiments (327). Moreover, infection by VZV induces a change in the repertoire of DCs available in the zone of the skin affected, which could be mainly related to the movement of these cells from and into the LN (327). It may be significant to highlight that the repertoire of DCs commonly detected in the skin are cDCs and LCs, and, after infection, monocyte-derived inflammatory DCs and pDCs are found (326-328). Accordingly, and as seen for HSV, DCs are capable of mounting a primary antiviral response upon VZV infection, therefore prompting the secretion of type I IFN and other proinflammatory molecules. However, VZV infection of DCs can be one of the mechanisms that this virus could use to disseminate in the organism (326).

Finally, human gammaherpesvirus 4 or EBV has been reported to infect over $90 \%$ of the world population, achieving latency and persistence in its host (329). This virus is associated with many diseases in humans, among which the appearance of tumors can be included -Hodgkin's lymphoma is one of the most remarkable among these (330). Surprisingly, EBV can also infect DCs, as seen for HSV and VZV (330). This virus can also be recognized by TLR3 and TLR9, therefore leading to the activation of the type I IFN pathway (331). The activation of this pathway has been shown to render B cells less prone to transformation induced by this virus, therefore partially restricting the symptoms of this disease (332). This environment will also induce the activation of other innate cells, such as NK cells and PMNs, that will aid in the control and clearance of this virus (331).

\section{REFERENCES}

1. Banchereau J, Steinman RM. Dendritic cells and the control of immunity. Nature. (1998) 392:245-52. doi: 10.1038/32588

2. Pollara G, Kwan A, Newton PJ, Handley ME, Chain BM, Katz DR. Dendritic cells in viral pathogenesis: protective or defective? Int J Exp Pathol. (2005) 86:187-204. doi: 10.1111/j.0959-9673.2005.00440.x

\section{CONCLUSIONS}

In this article, we have stated the significant part that DCs play during important infectious diseases that affect humans. Not only are they effector phagocytic cells that can contribute to IFNmediated antiviral responses, but they must also act as a bridge between the innate and adaptive immune response, activating lymphocytes, the key players of the adaptive response, so that these cells can effectively face the respective viral infection. DCs must perform this by recognizing either PAMPs or DAMPs through their vast arrays of PRRs, which will guide DCs -and another cells type- to the correct effector profile. Triggering of PRRs will induce signaling cascades that will eventually promote the secretion of several molecules with immune-related roles, such as cytokines and chemokines. Interferon is one of the most important cytokines related to the antiviral response, key to efficient clearance of the viruses from the hosts. Although several types of cells are capable of activating the type I IFN pathway -and therefore secreting this molecule-, DCs have a fundamental role in this process. They are strongly associated with the secretion of this cytokine, as they can recognize different components of the virus to activate this antiviral response efficiently, through the previously mentioned PRRs. Therefore, further therapeutic approaches against the discussed pathogens will require to focus on the role of these cells in order to effectively promote an immune response that comprises both the innate and adaptive branch of the immune system.

\section{AUTHOR CONTRIBUTIONS}

JS: conceptualization, writing original draft, review, editing, and revision. NG: writing original draft, review, editing, and revision. KB: writing original draft. CA: figure design, review, and revision. GP: writing original draft, review, and revision. RB: writing original draft. SB: editing and revision. AK: conceptualization, revision of original draft, editing, and revision. All authors listed have made substantial, direct, and intellectual contribution to the work and approved it for publication.

\section{FUNDING}

This work was supported by the Millennium Institute on Immunology and Immunotherapy (P09/016-F) and FONDECYT grants 3190590, 3180570, 1170964, 1190830 and CONICYT scholarship 21190183. AK is a Helen C. Levitt Visiting Professor at the Department of Microbiology and Immunology of the University of Iowa.
3. Banchereau J, Briere F, Caux C, Davoust J, Lebecque S, Liu YJ, et al. Immunobiology of dendritic cells. Annu Rev Immunol. (2000) 18:767811. doi: 10.1146/annurev.immunol.18.1.767

4. Steinman RM, Cohn ZA. Identification of a novel cell type in peripheral lymphoid organs of mice. I. Morphology, quantitation, tissue distribution. J Exp Med. (1973) 137:1142-62. doi: 10.1084/jem.137. 5.1142 
5. Buchta CM, Bishop GA. Toll-like receptors and B cells: functions and mechanisms. Immunol Res. (2014) 59:1222. doi: $10.1007 / \mathrm{s} 12026-014-8523-2$

6. Kumar H, Kawai T, Akira S. Pathogen recognition in the innate immune response. Biochem J. (2009) 420:1-16. doi: 10.1042/BJ20090272

7. Pène $J$, Chevalier $S$, Preisser $L$, Vénéreau $E$, Guilleux $M-H$, Ghannam S, et al. Chronically inflamed human tissues are infiltrated by highly differentiated Th17 lymphocytes. J Immunol. (2008) 180:7423-30. doi: 10.4049/jimmunol.180.11.7423

8. Takeuchi O, Akira S. Pattern recognition receptors and inflammation. Cell. (2010) 3:805-20. doi: 10.1016/j.cell.2010.01.022

9. Akira $S$, Uematsu $S$, Takeuchi O. Pathogen recognition and innate immunity. Cell. (2006) 124:783-801. doi: 10.1016/j.cell.2006.02.015

10. Yamamoto $M$, Takeda K. Current views of toll-like receptor signaling pathways. Gastroentrol Res Pract. (2010) 2010:240365. doi: 10.1155/2010/240365

11. Bowie A, O'Neill LAJ. The interleukin-1 receptor/Toll-like receptor superfamily: signal generators for pro-inflammatory interleukins and microbial products. J Leukoc Biol. (2000) 67:508-14. doi: 10.1002/jlb.67.4.508

12. Beutler B. Inferences, questions and possibilities in Toll-like receptor signalling. Nature. (2004) 430:257-63. doi: 10.1038/nature 02761

13. Tabeta K, Georgel P, Janssen E, Du X, Hoebe K, Crozat K, et al. Tolllike receptors 9 and 3 as essential components of innate immune defense against mouse cytomegalovirus infection. Proc Natl Acad Sci USA. (2004) 101:3516-21. doi: 10.1073/pnas.0400525101

14. Iwasaki A, Medzhitov R. Toll-like receptor control of the adaptive immune responses. Nat Immunol. (2004) 5:987-95. doi: 10.1038/ni1112

15. Martin SJ, Henry CM, Cullen SP. A perspective on mammalian caspases as positive and negative regulators of inflammation. Mol Cell. (2012) 46:38797. doi: 10.1016/j.molcel.2012.04.026

16. Garrett WS, Chen L-M, Kroschewski R, Ebersold M, Turley S, Trombetta S, et al. Developmental control of endocytosis in dendritic cells by Cdc42. Cell. (2000) 102:325-34. doi: 10.1016/S0092-8674(00)00038-6

17. Mellman I. Antigen processing for amateurs and professionals. Trends Cell Biol. (1998) 8:231-7. doi: 10.1016/S0962-8924(98)01276-8

18. Merad M, Sathe P, Helft J, Miller J, Mortha A. The dendritic cell lineage: ontogeny and function of dendritic cells and their subsets in the steady state and the inflamed setting. Annu Rev Immunol. (2013) 31:563-604. doi: 10.1146/annurev-immunol-020711-074950

19. Lanzavecchia A, Sallusto F. The instructive role of dendritic cells on $T$ cell responses: lineages, plasticity and kinetics. Curr Opin Immunol. (2001) 13:291-8. doi: 10.1016/S0952-7915(00)00218-1

20. Boniface JJ, Rabinowitz JD, Wülfing C, Hampl J, Reich Z, Altman JD, et al. Initiation of signal transduction through the $\mathrm{T}$ cell receptor requires the multivalent engagement of peptide/MHC ligands. Immunity. (1998) 9:459-66. doi: 10.1016/S1074-7613(00)80629-9

21. Heath WR, Belz GT, Behrens GMN, Smith CM, Forehan SP, Parish IA, et al. Cross-presentation, dendritic cell subsets, and the generation of immunity to cellular antigens. Immunol Rev. (2004) 199:9-26. doi: 10.1111/j.0105-2896.2004.00142.x

22. Rodriguez A, Regnault A, Kleijmeer M, Ricciardi-Castagnoli P, Amigorena S. Selective transport of internalized antigens to the cytosol for MHC class I presentation in dendritic cells. Nat Cell Biol. (1999) 1:3628. doi: $10.1038 / 14058$

23. Sprecher E, Becker Y. Langerhans cell density and activity in mouse skin and lymph nodes affect herpes simplex type 1 (HSV-1) pathogenicity. Arch Virol. (1989) 107:191-205. doi: 10.1007/BF01317916

24. Guerrero-Plata A, Casola A, Suarez G, Yu X, Spetch LA, Peeples ME, et al. Differential response of dendritic cells to human metapneumovirus and respiratory syncytial virus. Am J Respir Cell Mol Biol. (2006) 34:3209. doi: $10.1165 / \mathrm{rcmb} .2005-0287 \mathrm{OC}$

25. Onai N, Obata-Onai A, Schmid MA, Ohteki T, Jarrossay D, Manz MG. Identification of clonogenic common Flt3+M-CSFR+ plasmacytoid and conventional dendritic cell progenitors in mouse bone marrow. Nat Immunol. (2007) 8:1207-16. doi: 10.1038/ni1518

26. Naik SHH, Sathe P, Park H-YY, Metcalf D, Proietto AII, Dakic A, et al. Development of plasmacytoid and conventional dendritic cell subtypes from single precursor cells derived in vitro and in vivo. Nat Immunol. (2007) 8:1217-26. doi: 10.1038/ni1522

27. Reizis B, Bunin A, Ghosh HS, Lewis KL, Sisirak V. Plasmacytoid dendritic cells: recent progress and open questions. Annu Rev Immunol. (2011) 29:163-83. doi: 10.1146/annurev-immunol-031210-101345

28. Pelayo R, Hirose J, Huang J, Garrett KPP, Delogu A, Busslinger M, et al. Derivation of 2 categories of plasmacytoid dendritic cells in murine bone marrow. Blood. (2005) 105:4407-15. doi: 10.1182/blood-2004-07-2529

29. Corcoran L, Ferrero I, Vremec D, Lucas K, Waithman J, O’Keeffe M, et al. The lymphoid past of mouse plasmacytoid cells and thymic dendritic cells. $J$ Immunol. (2003) 170:4926-32. doi: 10.4049/jimmunol.170.10.4926

30. Guilliams M, Ginhoux F, Jakubzick C, Naik SH, Onai N, Schraml BU, et al. Dendritic cells, monocytes and macrophages: a unified nomenclature based on ontogeny. Nat Rev Immunol. (2014) 14:571-8. doi: 10.1038/nri3712

31. Gardner A, Ruffell B. Dendritic cells and cancer immunity. Trends Immunol. (2016) 37:855-65. doi: 10.1016/j.it.2016.09.006

32. Robbins SH, Walzer T, Dembélé D, Thibault C, Defays A, Bessou G, et al. Novel insights into the relationships between dendritic cell subsets in human and mouse revealed by genome-wide expression profiling. Genome Biol. (2008) 9:R17. doi: 10.1186/gb-2008-9-1-r17

33. Sancho D, Mourão-Sá D, Joffre OP, Schulz O, Rogers NC, Pennington DJ, et al. Tumor therapy in mice via antigen targeting to a novel, DC-restricted C-type lectin. J Clin Invest. (2008) 118:2098-110. doi: 10.1172/JCI34584

34. Dorner BG, Dorner MB, Zhou X, Opitz C, Mora A, Güttler S, et al. Selective expression of the chemokine receptor XCR1 on Cross-presenting dendritic cells determines cooperation with CD8+ T cells. Immunity. (2009) 31:82333. doi: 10.1016/j.immuni.2009.08.027

35. Crowley $M$, Inaba $K$, Witmer-Pack $M$, Steinman RM. The cell surface of mouse dendritic cells: FACS analyses of dendritic cells from different tissues including thymus. Cell Immunol. (1989) 118:108-25. doi: 10.1016/0008-8749(89)90361-4

36. Idoyaga J, Suda N, Suda K, Park CG, Steinman RM. Antibody to Langerin/CD207 localizes large numbers of CD8 + dendritic cells to the marginal zone of mouse spleen. Proc Natl Acad Sci USA. (2009) 106:15249. doi: $10.1073 /$ pnas. 0812247106

37. Vremec D, Zorbas M, Scollay R, Saunders DJ, Ardavin CF, Wu L, et al. The surface phenotype of dendritic cells purified from mouse thymus and spleen: investigation of the CD8 expression by a subpopulation of dendritic cells. $J$ Exp Med. (1992) 176:47-58. doi: 10.1084/jem.176.1.47

38. del Rio M-L, Bernhardt G, Rodriguez-Barbosa J-I, Förster R. Development and functional specialization of CD103 + dendritic cells. Immunol Rev. (2010) 234:268-81. doi: 10.1111/j.0105-2896.2009.00874.x

39. Poulin LF, Henri S, de Bovis B, Devilard E, Kissenpfennig A, Malissen B. The dermis contains langerin + dendritic cells that develop and function independently of epidermal Langerhans cells. J Exp Med. (2007) 204:311931. doi: $10.1084 /$ jem. 20071724

40. Ginhoux F, Collin MP, Bogunovic M, Abel M, Leboeuf M, Helft J, et al. Bloodderived dermal langerin + dendritic cells survey the skin in the steady state. $J$ Exp Med. (2007) 204:3133-46. doi: 10.1084/jem.20071733

41. Bursch LS, Wang L, Igyarto B, Kissenpfennig A, Malissen B, Kaplan DH, et al. Identification of a novel population of Langerin + dendritic cells. J Exp Med. (2007) 204:3147-56. doi: 10.1084/jem.20071966

42. Wylie B, Seppanen E, Xiao K, Zemek R, Zanker D, Prato S, et al. Cross-presentation of cutaneous melanoma antigen by migratory XCR1 + CD103 - and XCR1 + CD103 + dendritic cells. Oncoimmunology. (2015) 4:e1019198. doi: 10.1080/2162402X.2015.1019198

43. Jaensson E, Uronen-Hansson H, Pabst O, Eksteen B, Tian J, Coombes JL, et al. Small intestinal CD103+ dendritic cells display unique functional properties that are conserved between mice and humans. J Exp Med. (2008) 205:2139-49. doi: 10.1084/jem.20080414

44. Jongbloed SL, Kassianos AJ, McDonald KJ, Clark GJ, Ju X, Angel CE, et al. Human CD141+ (BDCA-3)+ dendritic cells (DCs) represent a unique myeloid DC subset that cross-presents necrotic cell antigens. J Exp Med. (2010) 207:1247-60. doi: 10.1084/jem.20092140

45. Haniffa M, Shin A, Bigley V, McGovern N, Teo P, See P, et al. Human tissues contain CD141hi cross-presenting dendritic cells with functional homology to mouse CD103+ nonlymphoid dendritic cells. Immunity. (2012) 37:60-73. doi: 10.1016/j.immuni.2012.04.012 
46. Bachem A, Güttler S, Hartung E, Ebstein F, Schaefer M, Tannert A, et al. Superior antigen cross-presentation and XCR1 expression define human CD11c + CD141+ cells as homologues of mouse CD $8+$ dendritic cells. J Exp Med. (2010) 207:1273-81. doi: 10.1084/jem.20100348

47. Guilliams M, Dutertre C-A, Scott CL, McGovern N, Sichien $\mathrm{D}$, Chakarov $\mathrm{S}$, et al. Unsupervised high-dimensional analysis aligns dendritic cells across tissues and species. Immunity. (2016) 45:669-84. doi: 10.1016/j.immuni.2016.08.015

48. Bogunovic M, Ginhoux F, Helft J, Shang L, Hashimoto D, Greter M, et al. Origin of the lamina propria dendritic cell network. Immunity. (2009) 31:513-25. doi: 10.1016/j.immuni.2009.08.010

49. Breton G, Zheng S, Valieris R, Tojal da Silva I, Satija R, Nussenzweig MC. Human dendritic cells (DCs) are derived from distinct circulating precursors that are precommitted to become CD1c+ or CD141+ DCs. J Exp Med. (2016) 213:2861-70. doi: 10.1084/jem.20161135

50. Martínez-Cingolani C, Grandclaudon M, Jeanmougin M, Jouve M, Zollinger R, Soumelis V. Human blood BDCA-1 dendritic cells differentiate into Langerhans-like cells with thymic stromal lymphopoietin and TGF- $\beta$. Blood. (2014) 124:2411-20. doi: 10.1182/blood-2014-04-568311

51. Greer AM, Matthay MA, Kukreja J, Bhakta NR, Nguyen CP, Wolters PJ, et al. Shin J-S. Accumulation of BDCA1+ dendritic cells in interstitial fibrotic lung diseases and Th2-high asthma. PLoS ONE. (2014) 9:e99084. doi: 10.1371/journal.pone.0099084

52. Thomas R, Lipsky PE. Human peripheral blood dendritic cell subsets. Isolation and characterization of precursor and mature antigen-presenting cells. J Immunol. (1994) 153:4016-28.

53. Milne P, Bigley V, Gunawan M, Haniffa M, Collin M. CD1c+ blood dendritic cells have Langerhans cell potential. Blood. (2015) 125:4703. doi: 10.1182/blood-2014-08-593582

54. Björck P. Isolation and characterization of plasmacytoid dendritic cells from Flt3 ligand and granulocyte-macrophage colony-stimulating factor-treated mice. Blood. (2001) 98:3520-6. doi: 10.1182/blood.V98.13.3520

55. LeibundGut-Landmann S, Waldburger J-M, e Sousa CR, Acha-Orbea $\mathrm{H}$, Reith W. MHC class II expression is differentially regulated in plasmacytoid and conventional dendritic cells. Nat Immunol. (2004) 5:899908. doi: 10.1038/ni1109

56. O’Keeffe M, Hochrein H, Vremec D, Caminschi I, Miller JL, Anders EM, et al. Mouse plasmacytoid cells: long-lived cells, heterogeneous in surface phenotype and function, that differentiate into $\operatorname{CD} 8(+)$ dendritic cells only after microbial stimulus. J Exp Med. (2002) 196:130719. doi: 10.1084/jem.20021031

57. Cella M, Jarrossay D, Facchetti F, Alebardi O, Nakajima H, Lanzavecchia A, et al. Plasmacytoid monocytes migrate to inflamed lymph nodes and produce large amounts of type I interferon. Nat Med. (1999) 5:91923. doi: $10.1038 / 11360$

58. Swiecki M, Colonna M. The multifaceted biology of plasmacytoid dendritic cells. Nat Rev Immunol. (2015) 15:471-85. doi: 10.1038/nri3865

59. Dzionek A, Fuchs A, Schmidt P, Cremer S, Zysk M, Miltenyi S, et al. BDCA-2, BDCA-3, and BDCA-4: three markers for distinct subsets of dendritic cells in human peripheral blood. J Immunol. (2000) 165:603746. doi: 10.4049/jimmunol.165.11.6037

60. Grouard G, Rissoan MC, Filgueira L, Durand I, Banchereau J, Liu YJ. The enigmatic plasmacytoid $\mathrm{T}$ cells develop into dendritic cells with interleukin (IL)-3 and CD40-ligand. J Exp Med. (1997) 185:1101111. doi: 10.1084/jem.185.6.1101

61. Vremec D, Pooley J, Hochrein H, Wu L, Shortman K. CD4 and CD8 expression by dendritic cell subtypes in mouse thymus and spleen. $J$ Immunol. (2000) 164:2978-86. doi: 10.4049/jimmunol.164.6.2978

62. Shortman K, Heath WR. The CD8+ dendritic cell subset. Immunol Rev. (2010) 234:18-31. doi: 10.1111/j.0105-2896.2009.00870.x

63. Kamath AT, Henri S, Battye F, Tough DF, Shortman K. Developmental kinetics and lifespan of dendritic cells in mouse lymphoid organs. Blood. (2002) 100:173441. doi: 10.1182/blood.V100.5.1734.h81702001734_1734_1741

64. Kamath AT, Pooley J, O’Keeffe MA, Vremec D, Zhan Y, Lew $\mathrm{AM}$, et al. The development, maturation, and turnover rate of mouse spleen dendritic cell populations. I Immunol. (2000) 165:6762-70. doi: 10.4049/jimmunol.165.12.6762
65. Schulz O, Diebold SS, Chen M, Näslund TI, Nolte MA, Alexopoulou L, et al. Toll-like receptor 3 promotes cross-priming to virus-infected cells. Nature. (2005) 433:887-92. doi: 10.1038/nature03326

66. Rizzitelli A, Vremec D, Villadangos JA, Mavaddat N, Wright MD, Shortman K. Switching from a restricted to an effective CD4T cell response by activating CD8+ murine dendritic cells with a Toll-like receptor 9 ligand. Eur J Immunol. (2005) 35:3209-20. doi: 10.1002/eji.200526231

67. Yarovinsky F. TLR11 activation of dendritic cells by a protozoan profilin-like protein. Science (80-). (2005) 308:1626-9. doi: 10.1126/science.1109893

68. Edwards AD, Diebold SS, Slack EMC, Tomizawa H, Hemmi $\mathrm{H}$, Kaisho $\mathrm{T}$, et al. Toll-like receptor expression in murine DC subsets: lack of TLR7 expression by CD8 $\alpha+$ DC correlates with unresponsiveness to imidazoquinolines. Eur J Immunol. (2003) 33:827-33. doi: 10.1002/eji.200323797

69. Hochrein H, Shortman K, Vremec D, Scott B, Hertzog P, O'Keeffe M. Differential production of IL-12, IFN- $\alpha$, and IFN- $\gamma$ by mouse dendritic cell subsets. J Immunol. (2001) 166:5448-55. doi: 10.4049/jimmunol.166.9.5448

70. Dudziak D, Kamphorst AO, Heidkamp GF, Buchholz VR, Trumpfheller C, Yamazaki S, et al. Differential antigen processing by dendritic cell subsets in vivo. Science (80-). (2007) 315:107-11. doi: 10.1126/science.1136080

71. Lauterbach H, Bathke B, Gilles S, Traidl-Hoffmann C, Luber CA, Fejer $\mathrm{G}$, et al. Mouse CD $8 \alpha+$ DCs and human BDCA3+ DCs are major producers of IFN- $\lambda$ in response to poly IC. J Exp Med. (2010) 207:270317. doi: 10.1084 /jem.20092720

72. Edelson BT, KC W, Juang R, Kohyama M, Benoit LA, Klekotka PA, et al. Peripheral CD103+ dendritic cells form a unified subset developmentally related to CD $8 \alpha+$ conventional dendritic cells. J Exp Med. (2010) 207:82336. doi: 10.1084/jem.20091627

73. Jiao Z, Bedoui S, Brady JL, Walter A, Chopin M, Carrington EM, et al. The closely related CD103+ dendritic cells (DCs) and lymphoid-resident CD8+ DCs differ in their inflammatory functions. PLoS ONE. (2014) 9:e91126. doi: 10.1371/journal.pone.0091126

74. Sung S-SJ, Fu SM, Rose CE, Gaskin F, Ju S-T, Beaty SR. A major lung CD103 $(\alpha$ E) $-\beta 7$ integrin-positive epithelial dendritic cell population expressing Langerin and tight junction proteins. J Immunol. (2006) 176:5683.15683. doi: 10.4049/jimmunol.176.9.5683

75. Heath WR, Carbone FR. Cross-presentation in viral immunity and selftolerance. Nat Rev Immunol. (2001) 1:126-34. doi: 10.1038/35100512

76. Böttcher JP, Bonavita E, Chakravarty P, Blees H, Cabeza-Cabrerizo M, Sammicheli S, et al. NK cells stimulate recruitment of $\mathrm{cDCl}$ into the tumor microenvironment promoting cancer immune control. Cell. (2018) 172:1022-37.e14. doi: 10.1016/j.cell.2018.01.004

77. Bedoui S, Whitney PG, Waithman J, Eidsmo L, Wakim L, Caminschi I, et al. Cross-presentation of viral and self antigens by skin-derived CD103+ dendritic cells. Nat Immunol. (2009) 10:488-95. doi: 10.1038/ni.1724

78. Kim TS, Braciale TJ. Respiratory dendritic cell subsets differ in their capacity to support the induction of virus-specific cytotoxic CD8 $+\mathrm{T}$ cell responses. PLoS ONE. (2009) 4:e4204. doi: 10.1371/journal.pone.0004204

79. Krueger PD, Kim TS, Sung S-SJ, Braciale TJ, Hahn YS. Liver-resident $\mathrm{CD} 103+$ dendritic cells prime antiviral CD8 $+\mathrm{T}$ cells in situ. J Immunol. (2015) 194:3213-22. doi: 10.4049/jimmunol.1402622

80. Coombes JL, Siddiqui KRR, Arancibia-Cárcamo CV, Hall J, Sun C-M, Belkaid Y, et al. A functionally specialized population of mucosal CD103+ DCs induces Foxp3 + regulatory T cells via a TGF- $\beta$ - and retinoic aciddependent mechanism. J Exp Med. (2007) 204:1757-64. doi: 10.1084/jem.200 70590

81. Qiu C-H, Miyake Y, Kaise H, Kitamura H, Ohara O, Tanaka M. Novel subset of $\mathrm{CD} 8 \alpha+$ dendritic cells localized in the marginal zone is responsible for tolerance to cell-associated antigens. J Immunol. (2009) 182:412736. doi: 10.4049/jimmunol.0803364

82. del Rio M-L, Rodriguez-Barbosa J-I, Kremmer E, Förster R. CD103 - and $\mathrm{CD} 103+$ bronchial lymph node dendritic cells are specialized in presenting and cross-presenting innocuous antigen to CD4 + and CD8 + T cells. $J$ Immunol. (2007) 178:6861-6. doi: 10.4049/jimmunol.178.11.6861

83. Annacker O, Coombes JL, Malmstrom V, Uhlig HH, Bourne T, Johansson-Lindbom B, et al. Essential role for CD103 in the $\mathrm{T}$ cell-mediated regulation of experimental colitis. J Exp Med. (2005) 202:1051-61. doi: 10.1084/jem.20040662 
84. Siddiqui KRR, Powrie F. CD103+ GALT DCs promote Foxp3 + regulatory T cells. Mucosal Immunol. (2008) 1 (Suppl. 1):S34-8. doi: 10.1038/mi.2008.43

85. Lewis KL, Caton ML, Bogunovic M, Greter M, Grajkowska LT, Ng D, et al. Notch2 receptor signaling controls functional differentiation of dendritic cells in the spleen and intestine. Immunity. (2011) 35:78091. doi: 10.1016/j.immuni.2011.08.013

86. Schlitzer A, McGovern N, Teo P, Zelante T, Atarashi K, Low D, et al. IRF4 transcription factor-dependent CD11b + dendritic cells in human and mouse control mucosal IL-17 cytokine responses. Immunity. (2013) 38:97083. doi: 10.1016/j.immuni.2013.04.011

87. Wu L, D'Amico A, Winkel KD, Suter M, Lo D, Shortman K. RelB is essential for the development of myeloid-related CD8 $\alpha$ - dendritic cells but not of lymphoid-related CD8 $\alpha+$ dendritic cells. Immunity. (1998) 9:83947. doi: 10.1016/S1074-7613(00)80649-4

88. Granot T, Senda T, Carpenter DJ, Matsuoka N, Weiner J, Gordon CL, et al. Griesemer A, Ho S-H, et al. Dendritic cells display subset and tissuespecific maturation dynamics over human life. Immunity. (2017) 46:50415. doi: 10.1016/j.immuni.2017.02.019

89. Tamoutounour S, Guilliams M, Montanana Sanchis F, Liu H, Terhorst D, Malosse $\mathrm{C}$, et al. Origins and functional specialization of macrophages and of conventional and monocyte-derived dendritic cells in mouse skin. Immunity. (2013) 39:925-38. doi: 10.1016/j.immuni.2013.10.004

90. Langlet C, Tamoutounour S, Henri S, Luche H, Ardouin L, Grégoire $\mathrm{C}$, et al. CD64 expression distinguishes monocytederived and conventional dendritic cells and reveals their distinct role during intramuscular immunization. J Immunol. (2012) 188:1751-60. doi: 10.4049/jimmunol.1102744

91. Papalexi E, Satija R. Single-cell RNA sequencing to explore immune cell heterogeneity. Nat Rev Immunol. (2018) 18:35-45. doi: 10.1038/nri.2017.76

92. Krishnaswamy JK, Gowthaman U, Zhang B, Mattsson J, Szeponik L, Liu D, et al. Migratory CD11b + conventional dendritic cells induce T follicular helper cell-dependent antibody responses. Sci Immunol. (2017) 2:eaam9169. doi: 10.1126/sciimmunol.aam9169

93. Flores-Langarica A, Cook C, Müller Luda K, Persson EK, Marshall $\mathrm{JL}$, Beristain-Covarrubias $\mathrm{N}$, et al. Intestinal CD103(+)CD11b $(+)$ cDC2 conventional dendritic cells are required for primary CD4 $(+)$ $\mathrm{T}$ and $\mathrm{B}$ cell responses to soluble flagellin. Front Immunol. (2018) 9:2409. doi: 10.3389/fimmu.2018.02409

94. Plantinga M, Guilliams M, Vanheerswynghels M, Deswarte K, BrancoMadeira F, Toussaint W, et al. Conventional and monocyte-derived $\mathrm{CD} 11 \mathrm{~b}+$ dendritic cells initiate and maintain $\mathrm{T}$ helper 2 cell-mediated immunity to house dust mite allergen. Immunity. (2013) 38:32235. doi: 10.1016/j.immuni.2012.10.016

95. Murakami R, Denda-Nagai K, Hashimoto S, Nagai S, Hattori M, Irimura T. A unique dermal dendritic cell subset that skews the immune response toward Th2. PLoS ONE. (2013) 8:e73270. doi: 10.1371/journal.pone.0073270

96. Gao Y, Nish SA, Jiang R, Hou L, Licona-Limón P, Weinstein JS, et al. Control of $\mathrm{T}$ helper 2 responses by transcription factor IRF4-dependent dendritic cells. Immunity. (2013) 39:722-32. doi: 10.1016/j.immuni.2013.08.028

97. Kinnebrew MA, Buffie CG, Diehl GE, Zenewicz LA, Leiner I, Hohl TM, et al. Interleukin 23 production by intestinal CD103+CD11b + dendritic cells in response to bacterial flagellin enhances mucosal innate immune defense. Immunity. (2012) 36:276-87. doi: 10.1016/j.immuni.2011.12.011

98. Zhang Q, Lee W-B, Kang J-S, Kim LK, Kim Y-J. Integrin CD11b negatively regulates Mincle-induced signaling via the Lyn-SIRP $\alpha$-SHP1 complex. Exp Mol Med. (2018) 50:e439. doi: 10.1038/emm.2017.256

99. Redpath SA, Heieis GA, Reynolds LA, Fonseca NM, Kim SSY, PeronaWright G. Functional specialization of intestinal dendritic cell subsets during Th2 helminth infection in mice. Eur J Immunol. (2018) 48:8798. doi: 10.1002/eji.201747073

100. Mayer JU, Demiri M, Agace WW, MacDonald AS, Svensson-Frej M, Milling SW. Different populations of CD11b+ dendritic cells drive Th2 responses in the small intestine and colon. Nat Commun. (2017) 8:15820. doi: $10.1038 /$ ncomms 15820

101. Ling GS, Bennett J, Woollard KJ, Szajna M, Fossati-Jimack L, Taylor $\mathrm{PR}$, et al. Integrin CD11b positively regulates TLR4-induced signalling pathways in dendritic cells but not in macrophages. Nat Commun. (2014) 5:3039. doi: $10.1038 /$ ncomms4039
102. Atif SM, Uematsu S, Akira S, McSorley SJ. CD103-CD11b+ dendritic cells regulate the sensitivity of CD4 T-cell responses to bacterial flagellin. Mucosal Immunol. (2014) 7:68-77. doi: 10.1038/mi.2013.25

103. Nakano H, Yanagita M, Gunn MD. CD11c(+)B220(+)Gr-1(+) cells in mouse lymph nodes and spleen display characteristics of plasmacytoid dendritic cells. J Exp Med. (2001) 194:1171-8. doi: 10.1084/jem.194.8.1171

104. Siegal FP, Kadowaki N, Shodell M, Fitzgerald-Bocarsly PA, Shah $\mathrm{K}$, Ho S, et al. The nature of the principal type 1 interferonproducing cells in human blood. Science (80-). (1999) 284:1835 LP-7. doi: 10.1126/science.284.5421.1835

105. Sozzani S, Vermi W, Del Prete A, Facchetti F. Trafficking properties of plasmacytoid dendritic cells in health and disease. Trends Immunol. (2010) 31:270-7. doi: 10.1016/j.it.2010.05.004

106. Penna G, Sozzani S, Adorini L. Cutting edge: selective usage of chemokine receptors by plasmacytoid dendritic cells. J Immunol. (2001) 167:18626. doi: 10.4049/jimmunol.167.4.1862

107. Krug A, Uppaluri R, Facchetti F, Dorner BG, Sheehan KCF, Schreiber RD, et al. Cutting edge: IFN-producing cells respond to CXCR3 ligands in the presence of CXCL12 and secrete inflammatory chemokines upon activation. J Immunol. (2002) 169:6079-83. doi: 10.4049/jimmunol.169.11.6079

108. Drobits B, Holcmann M, Amberg N, Swiecki M, Grundtner R, Hammer M, et al. Imiquimod clears tumors in mice independent of adaptive immunity by converting pDCs into tumor-killing effector cells. J Clin Invest. (2012) 122:575-85. doi: 10.1172/JCI61034

109. Wendland M, Czeloth N, Mach N, Malissen B, Kremmer E, Pabst O, et al. CCR9 is a homing receptor for plasmacytoid dendritic cells to the small intestine. Proc Natl Acad Sci USA. (2007) 104:634752. doi: 10.1073/pnas.0609180104

110. Wurbel M-A, McIntire MG, Dwyer P, Fiebiger E. CCL25/CCR9 interactions regulate large intestinal inflammation in a murine model of acute colitis. PLoS ONE. (2011) 6:e16442. doi: 10.1371/journal.pone.0016442

111. Sisirak V, Vey N, Vanbervliet B, Duhen T, Puisieux I, Homey B, et al CCR6/CCR10-mediated plasmacytoid dendritic cell recruitment to inflamed epithelia after instruction in lymphoid tissues. Blood. (2011) 118:513040. doi: 10.1182/blood-2010-07-295626

112. Liou L-Y, Blasius AL, Welch MJ, Colonna M, Oldstone MBA, Zuniga EI. In vivo conversion of BM plasmacytoid DC into CD11b+ conventional DC during virus infection. Eur J Immunol. (2008) 38:3388-94. doi: 10.1002/eji.200838282

113. Soumelis V, Liu Y-J. From plasmacytoid to dendritic cell: morphological and functional switches during plasmacytoid pre-dendritic cell differentiation. Eur J Immunol. (2006) 36:2286-92. doi: 10.1002/eji.200636026

114. Jego G, Palucka AK, Blanck J-P, Chalouni C, Pascual V, Banchereau J. Plasmacytoid dendritic cells induce plasma cell differentiation through type I interferon and interleukin 6. Immunity. (2003) 19:225-34. doi: 10.1016/S1074-7613(03)00208-5

115. Meixlsperger S, Leung CS, Rämer PC, Pack M, Vanoaica LD, Breton $\mathrm{G}$, et al. CD141+ dendritic cells produce prominent amounts of IFN$\alpha$ after dsRNA recognition and can be targeted via DEC-205 in humanized mice. Blood. (2013) 121:5034-44. doi: 10.1182/blood-2012-12473413

116. Jin J-O, Zhang W, Du J, Yu Q. BDCA1-positive dendritic cells (DCs) represent a unique human myeloid DC subset that induces innate and adaptive immune responses to Staphylococcus aureus infection. Infect Immun. (2014) 82:4466-76. doi: 10.1128/IAI.01851-14

117. Leal Rojas IM, Mok W-H, Pearson FE, Minoda Y, Kenna TJ, Barnard RT, et al. Human blood CD1c+ dendritic cells promote Th1 and Th17 effector function in memory CD4+ T cells. Front Immunol. (2017) 8:971. doi: 10.3389/fimmu.2017.00971

118. Hémont C, Neel A, Heslan M, Braudeau C, Josien R. Human blood mDC subsets exhibit distinct TLR repertoire and responsiveness. J Leukoc Biol. (2013) 93:599-609. doi: 10.1189/jlb.0912452

119. Sittig SP, Bakdash G, Weiden J, Sköld AE, Tel J, Figdor CG, et al. A comparative study of the $\mathrm{T}$ cell stimulatory and polarizing capacity of human primary blood dendritic cell subsets. Mediators Inflamm. (2016) 2016:1-11. doi: 10.1155/2016/3605643

120. Nizzoli G, Krietsch J, Weick A, Steinfelder S, Facciotti F, Gruarin $\mathrm{P}$, et al. Human CD1c+ dendritic cells secrete high levels of IL-12 
and potently prime cytotoxic T-cell responses. Blood. (2013) 122:93242. doi: 10.1182/blood-2013-04-495424

121. Durand M, Walter T, Pirnay T, Naessens T, Gueguen P, Goudot C, et al. Human lymphoid organ $\mathrm{CDC} 2$ and macrophages play complementary roles in $\mathrm{T}$ follicular helper responses. J Exp Med. (2019) 216:156181. doi: 10.1084 /jem.20181994

122. Segura E, Durand M, Amigorena S. Similar antigen cross-presentation capacity and phagocytic functions in all freshly isolated human lymphoid organ-resident dendritic cells. J Exp Med. (2013) 210:1035-47. doi: 10.1084/jem.20121103

123. Kim S, Kaiser V, Beier E, Bechheim M, Guenthner-Biller M, Ablasser A, et al. Self-priming determines high type I IFN production by plasmacytoid dendritic cells. Eur J Immunol. (2014) 44:807-18. doi: 10.1002/eji.201343806

124. Salvi V, Gianello V, Busatto S, Bergese P, Andreoli L, D’Oro U, et al. Exosomedelivered microRNAs promote IFN- $\alpha$ secretion by human plasmacytoid DCs via TLR7. JCI insight. (2018) 3:e98204. doi: 10.1172/jci.insight.98204

125. Jarrossay D, Napolitani G, Colonna M, Sallusto F, Lanzavecchia A. Specialization and complementarity in microbial molecule recognition by human myeloid and plasmacytoid dendritic cells. Eur J Immunol. (2001) 31:3388-93. doi: 10.1002/1521-4141(200111)31:11<3388::AIDIMMU3388>3.0.CO;2-Q

126. Kumagai Y, Kumar H, Koyama S, Kawai T, Takeuchi O, Akira S. Cutting edge: TLR-dependent viral recognition along with type I IFN positive feedback signaling masks the requirement of viral replication for IFN- $\alpha$ production in plasmacytoid dendritic cells. J Immunol. (2009) 182:3960 LP-4. doi: 10.4049/jimmunol.0804315

127. Johnson TR, Johnson CN, Corbett KS, Edwards GC, Graham BS. Primary human $\mathrm{mDC} 1, \mathrm{mDC}$, and $\mathrm{pDC}$ dendritic cells are differentially infected and activated by respiratory syncytial virus. PLOS ONE. (2011) 6:e16458. doi: 10.1371/journal.pone.0016458

128. See P, Lum J, Chen J, Ginhoux F. A single-cell sequencing guide for immunologists. Front Immunol. (2018) 9:2425. doi: $10.3389 /$ fimmu.2018.02425

129. Bassler K, Schulte-Schrepping J, Warnat-Herresthal S, Aschenbrenner AC, Schultze JL. The myeloid cell compartment-cell by cell. Annu Rev Immunol. (2019) 37:269-93. doi: 10.1146/annurev-immunol-042718041728

130. Alcántara-Hernández M, Leylek R, Wagar LE, Engleman EG, Keler T, Marinkovich MP, et al. High-dimensional phenotypic mapping of human dendritic cells reveals interindividual variation and tissue specialization. Immunity. (2017) 47:1037-50.e6. doi: 10.1016/j.immuni.2017.11.001

131. Giladi A, Paul F, Herzog Y, Lubling Y, Weiner A, Yofe I, et al. Singlecell characterization of haematopoietic progenitors and their trajectories in homeostasis and perturbed haematopoiesis. Nat Cell Biol. (2018) 20:83646. doi: 10.1038/s41556-018-0121-4

132. Jaitin DA, Kenigsberg E, Keren-Shaul H, Elefant N, Paul F, Zaretsky I, et al. Massively parallel single-cell RNA-seq for marker-free decomposition of tissues into cell types. Science (80-). (2014) 343:776 LP-9. doi: 10.1126/science.1247651

133. Villani A-C, Satija R, Reynolds G, Sarkizova S, Shekhar K, Fletcher J, et al. Single-cell RNA-seq reveals new types of human blood dendritic cells, monocytes, and progenitors. Science. (2017) 356:eaah4573. doi: 10.1126/science.aah4573

134. Yin X, Yu H, Jin X, Li J, Guo H, Shi Q, et al. Human blood CD1c+ dendritic cells encompass CD5high and CD5low subsets that differ significantly in phenotype, gene expression, and functions. J Immunol. (2017) 198:1553 LP-64. doi: 10.4049/jimmunol.1600193

135. Cheng M, Zhang X, Yu H, Du P, Plumas J, Chaperot L, et al. Characterization of species-specific genes regulated by E2-2 in human plasmacytoid dendritic cells. Sci Rep. (2015) 5:10752. doi: 10.1038/srep10752

136. Matsui T, Connolly JE, Michnevitz M, Chaussabel D, Yu C-I, Glaser C, et al. CD2 distinguishes two subsets of human plasmacytoid dendritic cells with distinct phenotype and functions. J Immunol. (2009) 182:681523. doi: 10.4049/jimmunol.0802008

137. Onai N, Asano J, Kurosaki R, Kuroda S, Ohteki T. Flexible fate commitment of E2-2high common DC progenitors implies tuning in tissue microenvironments. Int Immunol. (2017) 29:443-56. doi: 10.1093/intimm/dxx058
138. Rodrigues PF, Alberti-Servera L, Eremin A, Grajales-Reyes GE, Ivanek R, Tussiwand R. Distinct progenitor lineages contribute to the heterogeneity of plasmacytoid dendritic cells. Nat Immunol. (2018) 19:711-22. doi: 10.1038/s41590-018-0136-9

139. Bauer J, Dress RJ, Schulze A, Dresing P, Ali S, Deenen R, et al. Cutting edge: IFN- $\beta$ Expression in the spleen is restricted to a subpopulation of plasmacytoid dendritic cells exhibiting a specific immune modulatory transcriptome signature. J Immunol. (2016) 196:4447 LP-51. doi: 10.4049/jimmunol.1500383

140. Zilionis R, Engblom C, Pfirschke C, Savova V, Zemmour D, Saatcioglu HD, et al. Single-cell transcriptomics of human and mouse lung cancers reveals conserved myeloid populations across individuals and species. Immunity. (2019) 50:1317-34.e10. doi: 10.1016/j.immuni.2019.03.009

141. Zanoni I, Ostuni R, Capuano G, Collini M, Caccia M, Ronchi AE, et al. CD14 regulates the dendritic cell life cycle after LPS exposure through NFAT activation. Nature. (2009) 460:264-8. doi: 10.1038/nature08118

142. Alculumbre SG, Saint-André V, Di Domizio J, Vargas P, Sirven P, Bost P, et al. Diversification of human plasmacytoid predendritic cells in response to a single stimulus. Nat Immunol. (2018) 19:6375. doi: 10.1038/s41590-017-0012-z

143. Nestorowa S, Hamey FK, Pijuan Sala B, Diamanti E, Shepherd M, Laurenti E, et al. A single-cell resolution map of mouse hematopoietic stem and progenitor cell differentiation. Blood. (2016) 128:e20-31. doi: 10.1182/blood-2016-05-716480

144. Paul F, Arkin Y, Giladi A, Jaitin DA, Kenigsberg E, Keren-Shaul H, et al. Transcriptional heterogeneity and lineage commitment in myeloid progenitors. Cell. (2015) 163:1663-77. doi: 10.1016/j.cell.2015.11.013

145. Drissen R, Buza-Vidas N, Woll P, Thongjuea S, Gambardella A, Giustacchini A, et al. Distinct myeloid progenitor-differentiation pathways identified through single-cell RNA sequencing. Nat Immunol. (2016) 17:66676. doi: $10.1038 /$ ni.3412

146. See P, Dutertre C-A, Chen J, Günther P, McGovern N, Irac SE, et al. Mapping the human DC lineage through the integration of high-dimensional techniques. Science (80-). (2017) 356:eaag3009. doi: 10.1126/science.aag3009

147. Schlitzer A, Sivakamasundari V, Chen J, Sumatoh HR Bin, Schreuder J, Lum J, et al. Identification of $\mathrm{CDC} 1$ - and $\mathrm{CDC} 2$-committed DC progenitors reveals early lineage priming at the common DC progenitor stage in the bone marrow. Nat Immunol. (2015) 16:718-28. doi: 10.1038/ni.3200

148. Muller U, Steinhoff U, Reis L, Hemmi S, Pavlovic J, Zinkernagel R, et al. Functional role of type I and type II interferons in antiviral defense. Science (80-). (1994) 264:1918-21. doi: 10.1126/science.8009221

149. Isaacs A, Lindenmann J. Virus interference. I. The interferon. Proc $R$ Soc London Ser B - Biol Sci. (1957) 147:258-67. doi: 10.1098/rspb.1957.0048

150. Zhang K. Overview of interferon: characteristics, signaling and anti-cancer effect. Arch Biotechnol Biomed. (2017) 36:72537. doi: 10.29328/journal.hjb.1001001

151. Sheppard P, Kindsvogel W, Xu W, Henderson K, Schlutsmeyer S, Whitmore TEE, et al. IL-28, IL-29 and their class II cytokine receptor IL-28R. Nat Immunol. (2003) 4:63-8. doi: 10.1038/ni873

152. Kotenko SVV, Gallagher G, Baurin VV, Lewis-Antes A, Shen M, Shah NKK, et al. IFN- $\lambda$ s mediate antiviral protection through a distinct class II cytokine receptor complex. Nat Immunol. (2003) 4:69-77. doi: 10.1038/ni875

153. Vassileva G, Chen S-C, Zeng M, Abbondanzo S, Jensen $K$, Gorman D, et al. Expression of a novel murine type I IFN in the pancreatic islets induces diabetes in mice. J Immunol. (2003) 170:5748-55. doi: 10.4049/jimmunol.170.11.5748

154. van Pesch V, Lanaya H, Renauld J-C, Michiels T. Characterization of the murine alpha interferon gene family. J Virol. (2004) 78:821928. doi: 10.1128/JVI.78.15.8219-8228.2004

155. Paludan S, Bowie A. Immune sensing of DNA. Immunity. (2013) 38:87080. doi: 10.1016/j.immuni.2013.05.004

156. Iwasaki A. A virological view of innate immune recognition. Annu Rev Microbiol. (2012) 66:177-96. doi: 10.1146/annurev-micro-092611-150203

157. Stark GR, Darnell JE. The JAK-STAT pathway at twenty. Immunity. (2012) 36:503-14. doi: 10.1016/j.immuni.2012.03.013

158. Schoggins JW, Wilson SJ, Panis M, Murphy MY, Jones CT, Bieniasz P, et al. A diverse range of gene products are effectors of the type $\mathrm{i}$ interferon antiviral response. Nature. (2011) 472:481-5. doi: 10.1038/nature09907 
159. Levy DE, Darnell JE. STATs: transcriptional control and biological impact. Nat Rev Mol Cell Biol. (2002) 3:651-62. doi: 10.1038/nrm909

160. van Boxel-Dezaire AHHHH, Rani MRSRS, Stark GRR. Complex modulation of cell type-specific signaling in response to type I interferons. Immunity. (2006) 25:361-72. doi: 10.1016/j.immuni.2006.08.014

161. Lo MS, Brazas RM, Holtzman MJ. Respiratory Syncytial Virus nonstructural proteins NS1 and NS2 mediate inhibition of stat2 expression and alpha/beta interferon responsiveness. J Virol. (2005) 79:9315-9. doi: 10.1128/JVI.79.14.9315-9319.2005

162. Tassiulas I, Hu X, Ho H, Kashyap Y, Paik P, Hu Y, et al. Amplification of IFN$\alpha$-induced STAT1 activation and inflammatory function by Syk and ITAMcontaining adaptors. Nat Immunol. (2004) 5:1181-9. doi: 10.1038/ni1126

163. Ho HH, Ivashkiv LB. Role of STAT3 in type I interferon responses. J Biol Chem. (2006) 281:14111-8. doi: 10.1074/jbc.M511797200

164. Wang W-B, Levy DE, Lee C-K. Correction: STAT3 negatively regulates type I IFN-mediated antiviral response. J Immunol. (2011) 187:257885. doi: 10.4049/jimmunol.1190075

165. Akira S, Takeda K. Toll-like receptor signalling. Nat Rev Immunol. (2004) 5:461. doi: 10.1038/nri1391

166. Hoebe K, Janssen EM, Kim SO, Alexopoulou L, Flavell RA, Han J, et al. Upregulation of costimulatory molecules induced by lipopolysaccharide and double-stranded RNA occurs by Trif-dependent and Trif-independent pathways. Nat Immunol. (2003) 4:1223-9. doi: 10.1038/ni1010

167. Yamamoto M. Role of adaptor TRIF in the MyD88-independent toll-like receptor signaling pathway. Science (80-). (2003) 301:640-3. doi: 10.1126/science.1087262

168. Hemmi H, Kaisho T, Takeuchi O, Sato S, Sanjo H, Hoshino K, et al. Small anti-viral compounds activate immune cells via the TLR7 MyD88-dependent signaling pathway. Nat Immunol. (2002) 3:196200. doi: $10.1038 /$ ni758

169. Gantier MP, Tong S, Behlke MA, Xu D, Phipps S, Foster PS, et al. TLR7 is involved in sequence-specific sensing of singlestranded RNAs in human macrophages. J Immunol. (2008) 180:2117-24. doi: 10.4049/jimmunol.180.4.2117

170. Bao M, Liu Y-J. Regulation of TLR7/9 signaling in plasmacytoid dendritic cells. Protein Cell. (2013) 4:40-52. doi: 10.1007/s13238-012-2104-8

171. Hemmi H, Takeuchi O, Kawai T, Kaisho T, Sato S, Sanjo H, et al. A Toll-like receptor recognizes bacterial DNA. Nature. (2000) 408:7405. doi: $10.1038 / 35047123$

172. Kawai T, Sato S, Ishii KJJ, Coban C, Hemmi H, Yamamoto M, et al. Interferon- $\alpha$ induction through Toll-like receptors involves a direct interaction of IRF7 with MyD88 and TRAF6. Nat Immunol. (2004) 5:10618. doi: $10.1038 /$ ni1118

173. Kumar H, Kawai T, Akira S. Toll-like receptors and innate immunity. Biochem Biophys Res Commun. (2009) 1:13545. doi: 10.1016/j.bbrc.2009.08.062

174. Parker D, Prince A. Staphylococcus aureus induces type I IFN signaling in dendritic cells via TLR9. J Immunol. (2012) 189:4040-6. doi: 10.4049/jimmunol.1201055

175. Honda K, Yanai H, Mizutani T, Negishi H, Shimada N, Suzuki N, et al. Role of a transductional-transcriptional processor complex involving MyD88 and IRF-7 in Toll-like receptor signaling. Proc Natl Acad Sci USA. (2004) 101:15416-21. doi: 10.1073/pnas.0406933101

176. Kerkmann M, Rothenfusser S, Hornung V, Towarowski A, Wagner M, Sarris A, et al. Activation with CpG-A and CpG-B oligonucleotides reveals two distinct regulatory pathways of type I IFN synthesis in human plasmacytoid dendritic cells. J Immunol. (2003) 170:446574. doi: 10.4049/jimmunol.170.9.4465

177. Alexopoulou L, Holt AC, Medzhitov R, Flavell RA. Recognition of doublestranded RNA and activation of NF-kB by Toll-like receptor 3. Nature. (2001) 413:732-8. doi: $10.1038 / 35099560$

178. Oshiumi H, Matsumoto M, Funami K, Akazawa T, Seya T. TICAM-1, an adaptor molecule that participates in Toll-like receptor 3-mediated interferon- $\beta$ induction. Nat Immunol. (2003) 4:161-7. doi: 10.1038/ni886

179. Johnsen IB, Nguyen TT, Ringdal M, Tryggestad AM, Bakke O, Lien E, et al. Toll-like receptor 3 associates with $\mathrm{c}$-Src tyrosine kinase on endosomes to initiate antiviral signaling. EMBO J. (2006) 25:333546. doi: $10.1038 /$ sj.emboj. 7601222
180. Matsumoto M, Oshiumi H, Seya T. Antiviral responses induced by the TLR3 pathway. Rev Med Virol. (2011) 21:67-77. doi: 10.1002/rmv.680

181. Kurt-Jones EA, Popova L, Kwinn L, Haynes LM, Jones LP, Tripp RA, et al. Pattern recognition receptors TLR4 and CD14 mediate response to respiratory syncytial virus. Nat Immunol. (2000) 1:398401. doi: $10.1038 / 80833$

182. Kagan JC, Su T, Horng T, Chow A, Akira S, Medzhitov R. TRAM couples endocytosis of Toll-like receptor 4 to the induction of interferon- $\beta$. Nat Immunol. (2008) 9:361-8. doi: 10.1038/ni1569

183. Kawai T, Akira $\mathrm{S}$. The role of pattern-recognition receptors in innate immunity: update on toll-like receptors. Nat Immunol. (2010) 11:37384. doi: 10.1038/ni.1863

184. Ren J, Liu G, Go J, Kolli D, Zhang G, Bao X. Human metapneumovirus M22 protein inhibits innate immune response in monocyte-derived dendritic cells. PLoS ONE. (2014) 9:e91865. doi: 10.1371/journal.pone.0091865

185. Bohmwald K, Gálvez NMS, Canedo-Marroquín G, Pizarro-Ortega MS, Andrade-Parra C, Gómez-Santander F, et al. Contribution of cytokines to tissue damage during human respiratory syncytial virus infection. Front Immunol. (2019) 10:452. doi: 10.3389/fimmu.2019.00452

186. Obodai E, Odoom JK, Adiku T, Goka B, Wolff T, Biere B, et al. The significance of human respiratory syncytial virus (HRSV) in children from Ghana with acute lower respiratory tract infection: a molecular epidemiological analysis, 2006 and 2013-2014. PLoS ONE. (2018) 13:e0203788. doi: 10.1371/journal.pone.0203788

187. Cespedes PF, Bueno SM, Ramirez BA, Gomez RS, Riquelme S a, Palavecino CE, et al. Surface expression of the hRSV nucleoprotein impairs immunological synapse formation with T cells. Proc Natl Acad Sci USA. (2014) 111:E3214-23. doi: 10.1073/pnas.1400760111

188. van den Hoogen BGG, Bestebroer TMM, Osterhaus ADME, Fouchier RAM. Analysis of the genomic sequence of a human metapneumovirus. Virology. (2002) 295:119-32. doi: 10.1006/viro.2001.1355

189. Bao X, Liu T, Shan Y, Li K, Garofalo RP, Casola A. Human metapneumovirus glycoprotein G inhibits innate immune responses. PLoS Pathog. (2008) 4:77. doi: 10.1371/journal.ppat.1000077

190. Kolli D, Bao X, Liu T, Hong C, Wang T, Garofalo RP, et al. Human metapneumovirus glycoprotein G inhibits TLR4-dependent signaling in monocyte-derived dendritic cells. J Immunol. (2011) 187:47-54. doi: 10.4049/jimmunol.1002589

191. Waithman J, Mintern JD. Dendritic cells and influenza A virus infection. Virulence. (2012) 3:603-8. doi: 10.4161/viru.21864

192. Cao W, Taylor AK, Biber RE, Davis WG, Kim JH, Reber AJ, et al. Rapid differentiation of monocytes into type I IFN-producing myeloid dendritic cells as an antiviral strategy against influenza virus infection. J Immunol. (2012) 189:2257-65. doi: 10.4049/jimmunol.1200168

193. McAuley JL, Gilbertson BP, Trifkovic S, Brown LE, McKimm-Breschkin JL. Influenza virus neuraminidase structure and functions. Front Microbiol. (2019) 10:39. doi: 10.3389/fmicb.2019.00039

194. Wieland SF, Chisari F V. Stealth and cunning: hepatitis B and Hepatitis C Viruses. J Virol. (2005) 79:9369-80. doi: 10.1128/JVI.79.15.9369-93 80.2005

195. Hoofnagle JH. Course and outcome of hepatitis C. Hepatology. (2002) 36:s21-9. doi: 10.1053/jhep.2002.36227

196. Li K, Foy E, Ferreon JCM, Nakamura M, Ferreon ACM, Ikeda M, et al. Immune evasion by hepatitis $\mathrm{C}$ virus NS3/4A protease-mediated cleavage of the Toll-like receptor 3 adaptor protein TRIF. Proc Natl Acad Sci USA. (2005) 102:2992-7. doi: 10.1073/pnas.0408824102

197. Foy E, Li K, Sumpter R, Loo Y-M, Johnson CL, Wang C, et al. Control of antiviral defenses through hepatitis $\mathrm{C}$ virus disruption of retinoic acidinducible gene-I signaling. Proc Natl Acad Sci USA. (2005) 102:298691. doi: 10.1073/pnas.0408707102

198. Blood GA. Assessment of pathogens transmissible by blood. Human Immunodeficiency Virus (HIV). Transfus Med Hemotherapy. (2016) 43:20322. doi: $10.1159 / 000445852$

199. Fanales-Belasio E, Raimondo M, Suligoi B, Buttò S. HIV virology and pathogenetic mechanisms of infection: a brief overview. Ann dell'Istit Super Sanità. (2010) 46:5-14. doi: 10.1590/S0021-25712010000100002

200. Groves IJ, Coleman N. Pathogenesis of human papillomavirus-associated mucosal disease. J Pathol. (2015) 235:527-38. doi: 10.1002/path.4496 
201. Burd EM, Dean CL. Human Papillomarirus. Microbiol Spectr. (2016) 4:17. doi: $10.1128 /$ microbiolspec.DMIH2-0001-2015

202. Doorbar J, Quint W, Banks L, Bravo IG, Stoler M, Broker TR, et al. The biology and life-cycle of Human Papillomaviruses. Vaccine. (2012) 30:F5570. doi: 10.1016/j.vaccine.2012.06.083

203. Crosbie EJ, Einstein MH, Franceschi S, Kitchener HC. Human papillomavirus and cervical cancer. Lancet. (2013) 382:88999. doi: 10.1016/S0140-6736(13)60022-7

204. Challberg MD, Kelly TJ. Adenovirus DNA replication in vitro. Proc Natl Acad Sci USA. (1979) 76:655-9. doi: 10.1073/pnas.76.2.655

205. Sato S, Li K, Kameyama T, Hayashi T, Ishida Y, Murakami S, et al. The RNA sensor RIG-I dually functions as an innate sensor and direct antiviral factor for Hepatitis B Virus. Immunity. (2015) 42:12332. doi: 10.1016/j.immuni.2014.12.016

206. Cui GY, Diao HY. Recognition of HBV antigens and HBV DNA by dendritic cells. Hepatobiliary Pancreat Dis Int. (2010) 9:584-92.

207. Faure-Dupuy S, Lucifora J, Durantel D. Interplay between the Hepatitis B Virus and innate immunity: from an understanding to the development of therapeutic concepts. Viruses. (2017) 9:95. doi: 10.3390/v9050095

208. Scott JE, Davison AJ. The complete DNA sequence of Varicella-Zoster Virus. J Gen Virol. (1986) 67:1759-816. doi: 10.1099/0022-1317-67-9-1759

209. Baer R, Bankier AT, Biggin MD, Deininger PL, Farrell PJ, Gibson TJ, et al. DNA sequence and expression of the B95-8 Epstein-Barr virus genome. Nature. (1984) 310:207-11. doi: 10.1038/310207a0

210. Deng Y, Herbert JA, Robinson E, Ren L, Smyth RL, Smith CM. Neutrophil: airway epithelial interactions result in increased epithelial damage and viral clearance during RSV infection. J Virol. (2020) 94:e0216119. doi: $10.1101 / 2019.12 .20 .885624$

211. Wu YH, Lai ACY, Chi PY, Thio CLP, Chen WY, Tsai CH, et al. Pulmonary IL33 orchestrates innate immune cells to mediate respiratory syncytial virusevoked airway hyperreactivity and eosinophilia. Allergy Eur J Allergy Clin Immunol. (2020) 75:818-30. doi: 10.1111/all.14091

212. Carvajal JJ, Avellaneda AM, Salazar-Ardiles C, Maya JE, Kalergis AM, Lay MK. Host components contributing to Respiratory Syncytial Virus pathogenesis. Front Immunol. (2019) 10:2152. doi: 10.3389/fimmu.2019.02152

213. Tregoning JSS, Yamaguchi Y, Harker J, Wang B, Openshaw PJMJM. The role of $\mathrm{T}$ cells in the enhancement of respiratory syncytial virus infection severity during adult reinfection of neonatally sensitized mice. J Virol. (2008) 82:4115-24. doi: 10.1128/JVI.02313-07

214. Schmidt ME, Varga SM. The CD8 T cell response to respiratory virus infections. Front Immunol. (2018) 9:678. doi: 10.3389/fimmu.2018.00678

215. Retamal-Díaz A, Covián C, Pacheco GA, Castiglione-Matamala AT, Bueno SM, González PA, et al. Contribution of resident memory CD8+ T cells to protective immunity against respiratory syncytial virus and their impact on vaccine design. Pathogens. (2019) 8:147. doi: 10.3390/pathogens8030147

216. Wang H, Peters N, Schwarze J. Plasmacytoid dendritic cells limit viral replication, pulmonary inflammation, and airway hyperresponsiveness in Respiratory Syncytial Virus Infection. J Immunol. (2006) 177:626370. doi: 10.4049/jimmunol.177.9.6263

217. Boogaard I, van Oosten M, van Rijt LS, Muskens F, Kimman TG, Lambrecht $\mathrm{BN}$, et al. Respiratory syncytial virus differentially activates murine myeloid and plasmacytoid dendritic cells. Immunology. (2007) 122:65-72. doi: 10.1111/j.1365-2567.2007.02613.x

218. Fonseca W, Lukacs NW, Ptaschinski C. Factors affecting the immunity to respiratory syncytial virus: from epigenetics to microbiome. Front Immunol. (2018) 9:226. doi: 10.3389/fimmu.2018.00226

219. Schlender J, Hornung V, Finke S, Gunthner-Biller M, Marozin S, Brzozka K, et al. Inhibition of Toll-Like receptor 7- and 9-mediated alpha/beta interferon production in human plasmacytoid dendritic cells by Respiratory Syncytial Virus and Measles Virus. J Virol. (2005) 79:550715. doi: 10.1128/JVI.79.9.5507-5515.2005

220. Ascough S, Paterson S, Chiu C. Induction and subversion of human protective immunity: contrasting influenza and respiratory syncytial virus. Front Immunol. (2018) 9:323. doi: 10.3389/fimmu.2018.00323

221. Smit JJ, Rudd BD, Lukacs NW. Plasmacytoid dendritic cells inhibit pulmonary immunopathology and promote clearance of respiratory syncytial virus. J Exp Med. (2006) 203:1153-9. doi: 10.1084/jem.20052359
222. Hornung V, Schlender J, Guenthner-Biller M, Rothenfusser S, Endres S, Conzelmann $\mathrm{K}-\mathrm{K}$, et al. Replication-dependent potent IFN- $\alpha$ induction in human plasmacytoid dendritic cells by a single-stranded RNA Virus. $J$ Immunol. (2004) 173:5935-43. doi: 10.4049/jimmunol.173.10.5935

223. Shrestha B, You D, Saravia J, Siefker DTT, Jaligama S, Lee GII, et al. IL-4R $\alpha$ on dendritic cells in neonates and Th2 immunopathology in respiratory syncytial virus infection. J Leukoc Biol. (2017) 102:15361. doi: 10.1189/jlb.4A1216-536R

224. Gonzalez PA, Prado CE, Leiva ED, Carreno LJ, Bueno SM, Riedel CA, et al. Respiratory syncytial virus impairs $\mathrm{T}$ cell activation by preventing synapse assembly with dendritic cells. Proc Natl Acad Sci USA. (2008) 105:149995004. doi: $10.1073 /$ pnas. 0802555105

225. Kahn JS. Epidemiology of human metapneumovirus. Clin Microbiol Rev. (2006) 19:546-57. doi: 10.1128/CMR.00014-06

226. Kolli D, Bataki EL, Spetch L, Guerrero-Plata A, Jewell AM, Piedra PA, et al. T lymphocytes contribute to antiviral immunity and pathogenesis in experimental human metapneumovirus infection. J Virol. (2008) 82:85609. doi: 10.1128/JVI.00699-08

227. Palavecino CE, Cespedes PF, Lay MK, Riedel CA, Kalergis AM, Bueno SM. Understanding lung immunopathology caused by the human metapneumovirus: implications for rational vaccine design. Crit Rev Immunol. (2015) 35:185-202. doi: 10.1615/CritRevImmunol.2015013844

228. Tan MCC, Battini L, Tuyama ACC, Macip S, Melendi GAA, Horga M-AA, et al. Characterization of human metapneumovirus infection of myeloid dendritic cells. Virology. (2007) 357:1-9. doi: 10.1016/j.virol.2006.08.004

229. Céspedes PF, Gonzalez PA, Kalergis AM. Human metapneumovirus keeps dendritic cells from priming antigen-specific naive T cells. Immunology. (2013) 139:366-76. doi: 10.1111/imm.12083

230. Guerrero-Plata A, Baron S, Poast JS, Adegboyega PA, Casola A, Garofalo RP. Activity and regulation of alpha interferon in Respiratory Syncytial Virus and human metapneumovirus experimental infections. J Virol. (2005) 79:10190-9. doi: 10.1128/JVI.79.16.10190-10199.2005

231. Soto JA, Gálvez NMS, Benavente FM, Pizarro-Ortega MS, Lay MK, Riedel $\mathrm{C}$, et al. Human metapneumovirus: mechanisms and molecular targets used by the virus to avoid the immune system. Front Immunol. (2018) 9:2466. doi: $10.3389 /$ fimmu.2018.02466

232. Chen X, Liu S, Goraya MU, Maarouf M, Huang S, Chen J-L. Host immune response to influenza A Virus Infection. Front Immunol. (2018) 9:320. doi: 10.3389/fimmu.2018.00320

233. Smed-Sörensen A, Chalouni C, Chatterjee B, Cohn L, Blattmann P, Nakamura N, et al. Influenza a virus infection of human primary dendritic cells impairs their ability to cross-present antigen to CD8 T cells. PLoS Pathog. (2012) 8:2572. doi: 10.1371/journal.ppat.1002572

234. Hartmann BM, Li W, Jia J, Patil S, Marjanovic N, Martínez-Romero C, et al. Mouse dendritic cell (DC) Influenza Virus infectivity is much lower than that for human DCs and is hemagglutinin subtype dependent. J Virol. (2013) 87:1916-8. doi: 10.1128/JVI.02980-12

235. Liu W-C, Lin S-C, Yu Y-L, Chu C-L, Wu S-C. Dendritic cell activation by recombinant hemagglutinin proteins of H1N1 and H5N1 Influenza A Viruses. J Virol. (2010) 84:12011-7. doi: 10.1128/JVI.01316-10

236. Wong JP, Christopher ME, Viswanathan S, Karpoff N, Dai X, Das D, et al. Activation of toll-like receptor signaling pathway for protection against influenza virus infection. Vaccine. (2009) 27:3481-3. doi: 10.1016/j.vaccine.2009.01.048

237. Joffre O, Nolte MA, Spörri R, Sousa CRE. Inflammatory signals in dendritic cell activation and the induction of adaptive immunity. Immunol Rev. (2009) 227:234-47. doi: 10.1111/j.1600-065X.2008.00718.x

238. Zhong J, Gastaminza P, Cheng G, Kapadia S, Kato T, Burton DR, et al. Robust hepatitis C virus infection in vitro. Proc Natl Acad Sci USA. (2005) 102:9294-9. doi: 10.1073/pnas.0503596102

239. Alter MJ. Epidemiology of hepatitis C virus infection. World J Gastroenterol. (2007) 13:2436. doi: 10.3748/wjg.v13.i17.2436

240. Kanto T, Hayashi N, Takehara T, Tatsumi T, Kuzushita N, Ito A, et al. Impaired allostimulatory capacity of peripheral blood dendritic cells recovered from hepatitis C virus-infected individuals. J Immunol. (1999) 162:5584-91.

241. Auffermann-Gretzinger S, Keeffe EB, Levy S. Impaired dendritic cell maturation in patients with chronic, but not resolved, hepatitis 
C virus infection. Blood. (2001) 97:3171-6. doi: 10.1182/blood.V97. 10.3171

242. Bigger CB, Guerra B, Brasky KM, Hubbard G, Beard MR, Luxon BA, et al. Intrahepatic gene expression during chronic hepatitis C virus infection in Chimpanzees. J Virol. (2004) 78:13779-92. doi: 10.1128/JVI.78.24.13779-13792.2004

243. Takahashi K, Asabe S, Wieland S, Garaigorta U, Gastaminza P, Isogawa $\mathrm{M}$, et al. Plasmacytoid dendritic cells sense hepatitis C virus-infected cells, produce interferon, and inhibit infection. Proc Natl Acad Sci USA. (2010) 107:7431-6. doi: 10.1073/pnas.1002301107

244. Cheng G, Zhong J, Chisari F V. Inhibition of dsRNA-induced signaling in hepatitis C virus-infected cells by NS3 protease-dependent and independent mechanisms. Proc Natl Acad Sci USA. (2006) 103:8499504. doi: $10.1073 /$ pnas. 0602957103

245. Ulsenheimer A, Gerlach JT, Jung M-C, Gruener N, Wächtler M, Backmund $\mathrm{M}$, et al. Plasmacytoid dendritic cells in acute and chronic hepatitis $\mathrm{C}$ virus infection. Hepatology. (2005) 41:643-51. doi: 10.1002/hep.20592

246. Shiina M, Rehermann B. Cell culture-produced hepatitis C virus impairs plasmacytoid dendritic cell function. Hepatology. (2007) 47:385-95. doi: 10.1002/hep.21996

247. Dolganiuc A, Chang S, Kodys K, Mandrekar P, Bakis G, Cormier $\mathrm{M}$, et al. Hepatitis C Virus (HCV) core protein-induced, monocytemediated mechanisms of reduced IFN- $\alpha$ and plasmacytoid dendritic cell loss in chronic HCV infection. J Immunol. (2006) 177:675868. doi: 10.4049/jimmunol.177.10.6758

248. Nyamweya S, Hegedus A, Jaye A, Rowland-Jones S, Flanagan KL, Macallan DC. Comparing HIV-1 and HIV-2 infection: lessons for viral immunopathogenesis. Rev Med Virol. (2013) 23:221-40. doi: 10.1002/rmv.1739

249. Sharp PM, Hahn BH. Origins of HIV and the AIDS pandemic. Cold Spring Harb Perspect Med. (2011) 1:a006841. doi: 10.1101/cshperspect.a006841

250. Hemelaar J, Elangovan R, Yun J, Dickson-Tetteh L, Fleminger I, Kirtley S, et al. Global and regional molecular epidemiology of HIV-1, 1990-2015: a systematic review, global survey, and trend analysis. Lancet Infect Dis. (2019) 19:143-55. doi: 10.1016/S1473-3099(18)30647-9

251. Hazenberg MD, Otto SA, van Benthem BH, Roos MT, Coutinho RA, Lange JMA, et al. Persistent immune activation in HIV-1 infection is associated with progression to AIDS. AIDS. (2003) 17:1881-8. doi: 10.1097/00002030-200309050-00006

252. Okoye AA, Picker LJ. CD4+ T-cell depletion in HIV infection: mechanisms of immunological failure. Immunol Rev. (2013) 3:586-612. doi: 10.1111/imr.12066

253. Kawamura T, Koyanagi Y, Nakamura Y, Ogawa Y, Yamashita A, Iwamoto T, et al. Significant virus replication in langerhans cells following application of HIV to abraded skin: relevance to occupational transmission of HIV. J Immunol. (2008) 180:3297-304. doi: 10.4049/jimmunol.180.5.3297

254. Patterson S, Rae A, Hockey N, Gilmour J, Gotch F. Plasmacytoid dendritic cells are highly susceptible to human immunodeficiency virus type 1 infection and release infectious virus. J Virol. (2001) 75:67103. doi: 10.1128/JVI.75.14.6710-6713.2001

255. Murray SM, Zhang Y, Douek DC, Sekaly RP. Myeloid cells enriched for a dendritic cell population from people living with HIV have altered gene expression not restored by antiretroviral therapy. Front Immunol. (2020) 11:261. doi: 10.3389/fimmu.2020.00261

256. Pope M, Gezelter S, Gallo N, Hoffman L, Steinman RM. Low levels of HIV1 infection in cutaneous dendritic cells promote extensive viral replication upon binding to memory CD4+ T cells. J Exp Med. (1995) 182:204556. doi: $10.1084 /$ jem.182.6.2045

257. Wu L, KewalRamani VN. Dendritic-cell interactions with HIV: infection and viral dissemination. Nat Rev Immunol. (2006) 6:859-68. doi: 10.1038/nri1960

258. de Witte L, Nabatov A, Pion M, Fluitsma D, de Jong MAWP, de Gruijl T, et al. Langerin is a natural barrier to HIV-1 transmission by Langerhans cells. Nat Med. (2007) 13:367-71. doi: 10.1038/nm1541

259. Derby N, Martinelli E, Robbiani M. Myeloid dendritic cells in HIV-1 infection. Curr Opin HIV AIDS. (2011) 6:37984. doi: 10.1097/COH.0b013e3283499d63

260. Cohen KW, Dugast A-S, Alter G, McElrath MJ, Stamatatos L. HIV-1 singlestranded RNA induces CXCL13 secretion in human monocytes via TLR7 activation and plasmacytoid dendritic cell-derived type I IFN. J Immunol. (2015) 194:2769-75. doi: 10.4049/jimmunol.1400952

261. Di Domizio J, Blum A, Gallagher-Gambarelli M, Molens J-P, Chaperot L, Plumas J. TLR7 stimulation in human plasmacytoid dendritic cells leads to the induction of early IFN-inducible genes in the absence of type I IFN. Blood. (2009) 114:1794-802. doi: 10.1182/blood-2009-04-216770

262. Bourke NM, Napoletano S, Bannan C, Ahmed S, Bergin C, McKnight Á, et al Control of HIV infection by IFN- $\alpha$ : implications for latency and a cure. Cell Mol Life Sci. (2018) 75:775-83. doi: 10.1007/s00018-017-2652-4

263. O'Brien M, Manches O, Sabado RL, Jimenez Baranda S, Wang Y, Marie I, et al. Spatiotemporal trafficking of HIV in human plasmacytoid dendritic cells defines a persistently IFN- $\alpha$-producing and partially matured phenotype. J Clin Invest. (2011) 121:1088-101. doi: 10.1172/JCI44960

264. Scagnolari C, Antonelli G. Type I interferon and HIV: Subtle balance between antiviral activity, immunopathogenesis and the microbiome. Cytokine Growth Factor Rev. (2018) 40:1931. doi: 10.1016/j.cytogfr.2018.03.003

265. Aiello A, Giannessi F, Percario ZA, Affabris E. The involvement of plasmacytoid cells in HIV infection and pathogenesis. Cytokine Growth Factor Rev. (2018) 40:77-89. doi: 10.1016/j.cytogfr.2018.03.009

266. Lehmann C, Lafferty M, Garzino-Demo A, Jung N, Hartmann P, Fätkenheuer G, et al. Plasmacytoid dendritic cells accumulate and secrete interferon alpha in lymph nodes of HIV-1 patients. PLoS ONE. (2010) 5:e11110. doi: 10.1371/journal.pone.0011110

267. Sivro A, Su R-C, Plummer FA, Ball TB. Interferon responses in HIV infection: from protection to disease. AIDS Rev. (2014) 16:43-51.

268. Yang CH, Murti A, Pfeffer SR, Basu L, Kim JG, Pfeffer LM. IFNalpha /beta promotes cell survival by activating NF-kappa B. Proc Natl Acad Sci USA. (2000) 97:13631-6. doi: 10.1073/pnas.250477397

269. Manel N, Hogstad B, Wang Y, Levy DE, Unutmaz D, Littman DR. A cryptic sensor for HIV-1 activates antiviral innate immunity in dendritic cells. Nature. (2010) 467:214-7. doi: 10.1038/nature09337

270. Egawa N, Egawa K, Griffin H, Doorbar J. Human Papillomaviruses; epithelial tropisms, and the development of neoplasia. Viruses. (2015) 7:386390. doi: 10.3390/v7072802

271. Offringa R, de Jong A, Toes REM, van der Burg SH, Melief CJM. Interplay between Human Papillomaviruses and dendritic cells. Curr Top Microbiol Immunol. (2003). 276:215-40. doi: 10.1007/978-3-662-06508-2_10

272. Manickam A, Sivanandham M, Tourkova IL. Immunological role of dendritic cells in cervical cancer. Adv Exp Med Biol. (2007) 601:15562. doi: 10.1007/978-0-387-72005-0_16

273. Song D, Li H, Li H, Dai J. Effect of human papillomavirus infection on the immune system and its role in the course of cervical cancer (Review). Oncol Lett. (2015) 10:600-6. doi: 10.3892/ol.2015.3295

274. Yan M, Peng J, Jabbar IA, Liu X, Filgueira L, Frazer IH, et al. Despite differences between dendritic cells and Langerhans cells in the mechanism of papillomavirus-like particle antigen uptake, both cells cross-prime T cells. Virology. (2004) 324:297-310. doi: 10.1016/j.virol.2004.03.045

275. Garrido F, Ruiz-Cabello F, Cabrera T, Pérez-Villar JJ, López-Botet M, Duggan-Keen $\mathrm{M}$, et al. Implications for immunosurveillance of altered HLA class I phenotypes in human tumours. Immunol Today. (1997) 18:8995. doi: 10.1016/S0167-5699(96)10075-X

276. Feller L, Wood NH, Khammissa RA, Chikte UM, Meyerov R, Lemmer J. HPV modulation of host immune responses. SADJ. (2010) 65:266-8.

277. Piersma SJ. Immunosuppressive tumor microenvironment in cervical cancer patients. Cancer Microenviron. (2011) 4:36175. doi: 10.1007/s12307-011-0066-7

278. Zhang Y, Yang H, Barnie PA, Yang P, Su Z, Chen J, et al. The expression of Toll-like receptor 8 and its relationship with VEGF and Bcl-2 in Cervical Cancer. Int J Med Sci. (2014) 11:608-13. doi: 10.7150/ijms.8428

279. Hasan U. Human papillomavirus (HPV) deregulation of Toll-like receptor 9. Oncoimmunology. (2014) 3:e27257. doi: 10.4161/onci. 27257

280. Wang Y, Weng Y, Shi Y, Xia X, Wang S, Duan H. Expression and functional analysis of Toll-like Receptor 4 in human cervical carcinoma. J Membr Biol. (2014) 247:591-9. doi: 10.1007/s00232-014-9675-7

281. Walker F. Increased apoptosis in cervical intraepithelial neoplasia associated with HIV infection: implication of oncogenic human 
papillomavirus, caspases, and langerhans cells. Clin Cancer Res. (2005) 11:2451-8. doi: 10.1158/1078-0432.CCR-04-1795

282. Guess JC, McCance DJ. Decreased migration of langerhans precursor-like cells in response to human keratinocytes expressing Human Papillomavirus Type 16 E6/E7 Is Related to reduced macrophage inflammatory protein-3 production. J Virol. (2005) 79:14852-62. doi: 10.1128/JVI.79.23.14852-14862.2005

283. Jimenez-Flores R, Mendez-Cruz R, Ojeda-Ortiz J, Munoz-Molina R, Balderas-Carrillo O, de la Luz Diaz-Soberanes M, et al. High-risk human papilloma virus infection decreases the frequency of dendritic Langerhans' cells in the human female genital tract. Immunology. (2006) 117:2208. doi: 10.1111/j.1365-2567.2005.02282.x

284. Hubert P, Caberg J-H, Gilles C, Bousarghin L, Franzen-Detrooz E, Boniver J, et al. E-cadherin-dependent adhesion of dendritic and Langerhans cells to keratinocytes is defective in cervical human papillomavirus-associated (pre)neoplastic lesions. J Pathol. (2005) 206:346-55. doi: 10.1002/path.1771

285. McClelland M, Sanderson KE, Spieth J, Clifton SW, Latreille P, Courtney $\mathrm{L}$, et al. Complete genome sequence of Salmonella enterica serovar Typhimurium LT2. Nature. (2001) 413:852-6. doi: 10.1038/35101614

286. Fausch SC, Fahey LM, Da Silva DM, Kast WM. Human Papillomavirus can escape immune recognition through langerhans cell phosphoinositide 3-kinase activation. J Immunol. (2005) 174:7172-8. doi: 10.4049/jimmunol.174.11.7172

287. Scott M, Nakagawa M, Moscicki A-B. Cell-mediated immune response to Human Papillomavirus Infection. Clin Vaccine Immunol. (2001) 8:20920. doi: 10.1128/CDLI.8.2.209-220.2001

288. Tran TTP, Eichholz K, Amelio P, Moyer C, Nemerow GR, Perreau M, et al. Humoral immune response to adenovirus induce tolerogenic bystander dendritic cells that promote generation of regulatory T cells. PLOS Pathog. (2018) 14:e1007127. doi: 10.1371/journal.ppat.1007127

289. Hendrickx R, Stichling N, Koelen J, Kuryk L, Lipiec A, Greber UF. Innate immunity to adenovirus. Hum Gene Ther. (2014) 25:26584. doi: 10.1089/hum.2014.001

290. Sharma PK, Dmitriev IP, Kashentseva EA, Raes G, Li L, Kim SW, et al. Development of an adenovirus vector vaccine platform for targeting dendritic cells. Cancer Gene Ther. (2018) 25:27-38. doi: 10.1038/s41417-017-0002-1

291. Eichholz K, Bru T, Tran TTP, Fernandes P, Welles H, Mennechet FJD, et al. Immune-complexed Adenovirus induce AIM2mediated pyroptosis in human dendritic cells. PLOS Pathog. (2016) 12:e1005871. doi: 10.1371/journal.ppat.1005871

292. Iacobelli-Martinez M, Nemerow GR. Preferential activation of Toll-Like Receptor Nine by CD46-utilizing Adenoviruses. J Virol. (2007) 81:130512. doi: 10.1128/JVI.01926-06

293. Cerullo V, Seiler MP, Mane V, Brunetti-Pierri N, Clarke C, Bertin TK, et al. Toll-like receptor 9 triggers an innate immune response to helper-dependent Adenoviral Vectors. Mol Ther. (2007) 15:378-85. doi: 10.1038/sj.mt. 6300031

294. Appledorn DM, Patial S, McBride A, Godbehere S, Van Rooijen N, Parameswaran N, et al. Adenovirus vector-induced innate inflammatory mediators, MAPK signaling, as well as adaptive immune responses are dependent upon both TLR2 and TLR9 in vivo. J Immunol. (2008) 181:213444. doi: 10.4049/jimmunol.181.3.2134

295. Doronin K, Flatt JW, Di Paolo NC, Khare R, Kalyuzhniy O, Acchione M, et al. Coagulation factor $\mathrm{X}$ activates innate immunity to human species $\mathrm{C}$ Adenovirus. Science (80-). (2012) 338:795-8. doi: 10.1126/science.1226625

296. Hartman ZC, Black EP, Amalfitano A. Adenoviral infection induces a multi-faceted innate cellular immune response that is mediated by the toll-like receptor pathway in A549 cells. Virology. (2007) 358:35772. doi: 10.1016/j.virol.2006.08.041

297. Hartman ZC, Kiang A, Everett RS, Serra D, Yang XY, Clay TM, et al. Adenovirus infection triggers a rapid, MyD88-regulated transcriptome response critical to acute-phase and adaptive immune responses in vivo. J Virol. (2007) 81:1796-812. doi: 10.1128/JVI.01936-06

298. Rademacher C, Bru T, McBride R, Robison E, Nycholat CM, Kremer EJ, et al. A Siglec-like sialic-acid-binding motif revealed in an adenovirus capsid protein. Glycobiology. (2012) 22:1086-91. doi: 10.1093/glycob/cws073
299. Maier O, Marvin SA, Wodrich H, Campbell EM, Wiethoff CM. Spatiotemporal dynamics of Adenovirus membrane rupture and endosomal escape. J Virol. (2012) 86:10821-8. doi: 10.1128/JVI.01428-12

300. Stein SC, Falck-Pedersen E. Sensing Adenovirus infection: activation of interferon regulatory factor 3 in RAW 264.7 cells. J Virol. (2012) 86:452737. doi: 10.1128/JVI.07071-11

301. Barlan AU, Griffin TM, Mcguire KA, Wiethoff CM. Adenovirus membrane penetration activates the NLRP3 inflammasome. J Virol. (2011) 85:14655. doi: 10.1128/JVI.01265-10

302. Peeridogaheh H, Meshkat Z, Habibzadeh S, Arzanlou M, Shahi JM, Rostami $\mathrm{S}$, et al. Current concepts on immunopathogenesis of hepatitis B virus infection. Virus Res. (2018) 245:29-43. doi: 10.1016/j.virusres.2017.12.007

303. Sun H, Zhou D, Zhou J. The role of DCs in the immunopathogenesis of chronic HBV infection and the methods of inducing DCs maturation. J Med Virol. (2016) 88:13-20. doi: 10.1002/jmv.24306

304. Wieland S, Thimme R, Purcell RH, Chisari F V. Genomic analysis of the host response to hepatitis B virus infection. Proc Natl Acad Sci USA. (2004) 101:6669-74. doi: 10.1073/pnas.0401771101

305. Dunn C, Peppa D, Khanna P, Nebbia G, Jones M, Brendish N, et al. Temporal analysis of early immune responses in patients with acute hepatitis B virus infection. Gastroenterology. (2009) 137:1289300. doi: 10.1053 /j.gastro.2009.06.054

306. Das A, Ellis G, Pallant C, Lopes AR, Khanna P, Peppa D, et al. IL-10Producing regulatory $\mathrm{B}$ cells in the pathogenesis of chronic hepatitis $\mathrm{B}$ virus infection. J Immunol. (2012) 189:3925-35. doi: 10.4049/jimmunol.1103139

307. Golsaz-Shirazi F, Amiri MM, Shokri F. Immune function of plasmacytoid dendritic cells, natural killer cells, and their crosstalk in HBV infection. Rev Med Virol. (2018) 28:e2007. doi: 10.1002/rmv.2007

308. Gripon P, Rumin S, Urban S, Le Seyec J, Glaise D, Cannie I, et al. Infection of a human hepatoma cell line by hepatitis B virus. Proc Natl Acad Sci USA. (2002) 99:15655-60. doi: 10.1073/pnas.232137699

309. Huang Z, Ge J, Pang J, Liu H, Chen J, Liao B, et al. Aberrant expression and dysfunction of TLR2 and its soluble form in chronic HBV infection and its regulation by antiviral therapy. Antiviral Res. (2015) 118:109. doi: 10.1016/j.antiviral.2015.03.004

310. Cooper A, Tal G, Lider O, Shaul Y. Cytokine induction by the hepatitis B virus capsid in macrophages is facilitated by membrane heparan sulfate and involves TLR2. J Immunol. (2005) 175:316576. doi: 10.4049/jimmunol.175.5.3165

311. Peterson DL, Van Houtte F, Gomez-Gutierrez J, Vanlandschoot P, Gavilanes F, Roobrouck A, et al. LPS-binding protein and CD14-dependent attachment of hepatitis B surface antigen to monocytes is determined by the phospholipid moiety of the particles. J Gen Virol. (2002) 83:227989. doi: 10.1099/0022-1317-83-9-2279

312. van Montfoort N, van der Aa E, van den Bosch A, Brouwers $\mathrm{H}$, Vanwolleghem T, Janssen HLA, et al. Hepatitis B Virus surface antigen activates myeloid dendritic cells via a soluble CD14-dependent mechanism. J Virol. (2016) 90:6187-99. doi: 10.1128/JVI.02903-15

313. Yonejima A, Mizukoshi E, Tamai T, Nakagawa H, Kitahara M, Yamashita $\mathrm{T}$, et al. Characteristics of impaired dendritic cell function in patients with Hepatitis B Virus infection. Hepatology. (2019) 70:25-39. doi: 10.1002/hep.30637

314. Martinet J, Dufeu-Duchesne T, Bruder Costa J, Larrat S, Marlu A, Leroy $\mathrm{V}$, et al. Altered functions of plasmacytoid dendritic cells and reduced cytolytic activity of natural killer cells in patients with chronic HBV infection. Gastroenterology. (2012) 143:1586-96.e8. doi: 10.1053/j.gastro.2012.08.046

315. Woltman AM, den Brouw MLO, Biesta PJ, Shi CC, Janssen HLA. Hepatitis b virus lacks immune activating capacity, but actively inhibits plasmacytoid dendritic cell function. PLoS ONE. (2011) 6:e15324. doi: 10.1371/journal.pone.0015324

316. Wang FS, Xing LH, Liu MX, Zhu CL, Liu HG, Wang HF, et al. Dysfunction of peripheral blood dendritic cells from patients with chronic hepatitis B virus infection. World J Gastroenterol. (2001) 7:537-41. doi: 10.3748/wjg.v7.i4.537

317. Op Den Brouw ML, Binda RS, Van Roosmalen MH, Protzer U, Janssen HLA, Van Der Molen RG, et al. Hepatitis B virus surface antigen impairs myeloid dendritic cell function: a possible immune escape mechanism of hepatitis B virus. Immunology. (2009) 126:280-9. doi: 10.1111/j.1365-2567.2008.02896.x 
318. King AMQQ, Lefkowitz EJ, Mushegian AR, Adams MJ, Dutilh BE, Gorbalenya $\mathrm{AE}$, et al. Changes to taxonomy and the International Code of Virus Classification and Nomenclature ratified by the International Committee on Taxonomy of Viruses 2018. Arch Virol. (2018) 163:260131. doi: 10.1007/s00705-018-3847-1

319. Steiner I. Herpes virus infection of the peripheral nervous system. Handbook Clin Neurol. (2013) 115:543-58. doi: 10.1016/B978-0-444-52902-2.00031-X

320. Chew T, Taylor K, Mossman K. Innate and adaptive immune responses to herpes simplex virus. Viruses. (2009) 1:979-1002. doi: 10.3390/v1030979

321. Amin I, Younas S, Afzal S, Shahid M, Idrees M. Herpes simplex virus type 1 and host antiviral immune responses: an update. Viral Immunol. (2019) 32:vim.2019.0097. doi: 10.1089/vim.2019.0097

322. Ma Y, He B. Recognition of herpes simplex viruses: Toll-like receptors and beyond. J Mol Biol. (2014) 426:1133-47. doi: 10.1016/j.jmb.2013. 11.012

323. Xing J, Wang S, Lin R, Mossman KL, Zheng C. Herpes simplex virus 1 tegument protein US11 downmodulates the RLR signaling pathway via direct interaction with RIG-I and MDA-5. J Virol. (2012) 86:352840. doi: 10.1128/JVI.06713-11

324. Bosnjak L, Miranda-Saksena M, Koelle DM, Boadle RA, Jones CA, Cunningham AL. Herpes simplex virus infection of human dendritic cells induces apoptosis and allows cross-presentation via uninfected dendritic cells. J Immunol. (2005) 174:2220-7. doi: 10.4049/jimmunol.174. 4.2220

325. Retamal-Díaz AR, Kalergis AM, Bueno SM, González PA. A herpes simplex virus type 2 deleted for glycoprotein $\mathrm{D}$ enables dendritic cells to activate CD4+ and CD8+ T cells. Front Immunol. (2017) 8:904. doi: 10.3389/fimmu.2017.00904

326. Schönrich G, Raftery MJ. Dendritic cells as Achilles' heel and Trojan horse during varicella zoster virus infection. Front Microbiol. (2015) 6:417 doi: 10.3389/fmicb.2015.00417
327. Gutzeit C, Raftery MJ, Peiser M, Tischer KB, Ulrich M, Eberhardt $\mathrm{M}$, et al. Identification of an important immunological difference between virulent Varicella-Zoster Virus and its avirulent vaccine: viral disruption of dendritic cell instruction. J Immunol. (2010) 185:48897. doi: 10.4049/jimmunol.0902817

328. Huch JH, Cunningham AL, Arvin AM, Nasr N, Santegoets SJAM, Slobedman E, et al. Impact of Varicella-Zoster virus on dendritic cell subsets in human skin during natural infection. J Virol. (2010) 84:406072. doi: 10.1128/JVI.01450-09

329. Young LS, Rickinson AB. Epstein-Barr virus: 40 years on. Nat Rev Cancer. (2004) 4:757-68. doi: 10.1038/nrc1452

330. Münz C. Dendritic cells during Epstein Barr virus infection. Front Microbiol. (2014) 5:308. doi: 10.3389/fmicb.2014.00308

331. Lünemann $\mathrm{A}$, Rowe $\mathrm{M}$, Nadal $\mathrm{D}$. Innate immune recognition of EBV. Curr Top Microbiol Immunol. (2015) 391:26587. doi: 10.1007/978-3-319-22834-1_9

332. Lotz M, Tsoukas CD, Fong S, Carson DA, Vaughan JH. Regulation of EpsteinBarr virus infection by recombinant interferons. Selected sensitivity to interferon- $\gamma$. Eur J Immunol. (1985) 15:520-5. doi: 10.1002/eji.1830150518

Conflict of Interest: The authors declare that the research was conducted in the absence of any commercial or financial relationships that could be construed as a potential conflict of interest.

Copyright (C) 2020 Soto, Gálvez, Andrade, Pacheco, Bohmwald, Berrios, Bueno and Kalergis. This is an open-access article distributed under the terms of the Creative Commons Attribution License (CC BY). The use, distribution or reproduction in other forums is permitted, provided the original author(s) and the copyright owner(s) are credited and that the original publication in this journal is cited, in accordance with accepted academic practice. No use, distribution or reproduction is permitted which does not comply with these terms. 